\title{
環境騒音の純音聴力への影響調查について
}

\author{
東邦大学耳覺咽喉科学教室（主住：名越好古教授) \\ 岡田罚 \\ 東京大学耳覞咽喉科学教室（主任：佐藤靖雄教授） \\ 野 村 恭 也 \\ 大阪大学耳䁷咽喉科学教室 (主任: 内藤 儶教授) \\ 酒井國男 \\ 東京慈恵会医科大学耳絪咽喉科学教室（主任：本多芳男教授） \\ 関 和 夫 \\ 和歌山医科大学耳鼠咽㗱科学教室 (主任: 舆田 榆教授)

三楽病院 口幸 作

まえがき

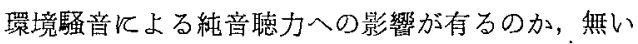
のかの点についての諭議は幾度かなされているが， S. Rosen による純音聴力検查報告以外のものは, 確 たる調查条件をつけた報告もないために, 純音聴力に ついての調查研究が普遍的になっている現在でさえ も, はっきりした結論は出されていない。S. Rosen よる高い周波数の純音聴力検查報告についても, 高い 周波数の域值検査用受話器が独自のものであること， 暗騒音条件，拈よび検査法が同一でないので，ある程 度定性比較的な意味も含めた定量比較的な報告と考え られる。

近時, 環境騒音が公害源としてクローズアップされ るようになると, 環境騒音の純音聴力への影響が再び 話題として論議されるようになってきている。

そこで, 私達は, 日常生活を営九でいる環境得時, あるいは周期的, 断続的飞存在するいわゆる㻴境騒音 が，果たしてどの程度の影響を純沓聴力域值に与えて いるかを求めるために, 調査地域を, 環境騒音が常識 的に明らかに認められる地域と, 騒音と呼ぶべきすの がほとんど認められない無騷音地域を選び，その地域 に長期飞わたって居住する人達を対象の純音域值聴力 検査を行ない，比較検討を重ねてきた。以下はをの一 部をなす $250 \mathrm{~Hz}$ より $8,000 \mathrm{~Hz}$ までの純音域値検查 成績を比較した報告である。

\section{検 査対象地域}

1）兵車県伊丹市地区，航空機騒音レベルが，WECPNL* $85 \mathrm{~dB}$ 以上の地域

2）大阪府豊中市地区, 航空機騒音レベルが, WECPNL* $85 \mathrm{~dB}$ 以上の地区

3）東京都大田区羽田地区, WECPNL* $85 \mathrm{~dB}$ 以上 の地域

4）東京都江戸川区地区幹線道路飞面する商店街, $\mathrm{A}$ 特性で $80 \mathrm{~dB}$ 以上(そのほとんどは $85 \mathrm{~dB}$ 前後)

5）岩手県宮古市郊外花輪地区の農村地帯

6）岩手県宮古市郊外津軽石地区の漁村地域

7）山形県寒河江汸大江地区

8）枋木県那須郡小川町片平地区

9）和歌山県那賀郡那賀町地区

\section{調查対象टなる被検者の条件}

1）兵而県伊丹市役所，大阪国際空港メディカルセ ンタ一, 東京都大田区役所, 東京都江戸川区役所, 岩手 県宮古市役所, 県立宮古病院, 山形県寒河江大江教育 委員会, 栃木県那須郡小川町役場, 和歌山県那賀郡那

* WECPNL

Weighted Equivalent Continuous Perceived Noise Level

荷重等価平均感覚騒音レベルの略。 航空機騒音のレベルの大きさを表現する一つの方 法。 
賀町役場汇和願いして，住民原簿の中から(1)同じ居住 地江 7 年以上住んでいる人，(可昼間も同じ地域活る 人で他地区に勤務飞出ない人であること，〈性別は男 女, いずれでもよい，(満20歳より35歳までの範囲内 の人などの条件をみたすものを抽出して頂き，アンケ 一ト方式でこの聴力検查济力していただくことを確 かめ, 日時を決めて, それぞれの検查所で検査をうけ る段取りとした。この検查には住民原簿の約 20 分の 1 の人達が応した。

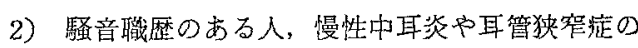
既往あるいは現病歴のある人や，邀伝性の聴力障害の ある人などのように，感音難聴や伝音䡩聴のある人達 は, 問診扣よび耳鼻喉咽科所見により,データ中から 省くようにした。

\section{検 查 室}

1）兵宣県伊丹市地区の第 1 グループは，地区公民 館のうち, 特飞暗騒音レベルの低い部屋の一隅にリオ ン製防音室 AT $4 \mathrm{C}$ を設置し，その中で検查を行な った。暗騷音レベル $45 \mathrm{~dB}(\mathrm{C})$

口）兵庫県伊丹市地区の第 2 グループならびに，大 阪府豊中市地区のグループは, 检查条件を変更し, 被 検者を委託車で阪大耳舀科防音室飞集め，検査を行な ったものである。喑騷音レベルは $50 \mathrm{~dB}$ (C)

八) 東京都大田区羽田地区は, 蒲田医師会館 2 階の 会議室に，リオン製防音室 AT $4 \mathrm{C}$ を設置して行なっ た。暗騒音はベルは $30 \mathrm{~dB}(\mathrm{~A})$

）東京都江戸川区地区は，江戸川医師会館内恥力 検查室で行なった。暗騷音レベル $40 \mathrm{~dB}(\mathrm{~A})$

本）岩手県宮古市郊外，花輪地区，ならび飞津軽不 地区では, 地区公民館内にリオン製防音室 AT $4 \mathrm{C}$ を 設造して行なった。花輪 $32 \mathrm{~dB}(\mathrm{~A}) .48 \mathrm{~dB}(\mathrm{C})$, 津 軽石 $25 \mathrm{~dB}$ (A), $47 \mathrm{~dB}$ (C)

へ) 山形県寒河江地区では, 大江地区高校内に防音 室 AT 4C を設置して行なった。 $35 \mathrm{~dB}(\mathrm{~A}), 50 \mathrm{~dB}$ (C)

卜）栃木県那須郡小川町寺院本堂内, $30 \mathrm{~dB}(\mathrm{~A})$, $47 \mathrm{~dB}$ (C)

チ) 和歌山県那贺郡那賀町地区では，地区児童館内 Kリオン製防音室 AT $4 \mathrm{C}$ を設置して検查を行なっ た。 $31 \mathrm{~dB}(\mathrm{~A}), 41 \mathrm{~dB}(\mathrm{C})$

\section{検 查 機 器}

JIS 規格オージオメータではマイナス側にスケー
ル・アウトする場合がしばしばあること，検查成績の 発表が国際的には JISでは不能なこと，ならび林 より ISO への换算が不可能であるなどの理由で，本 邦以外の先淮各国の使用している ISO 規格オージオ メータを使用することとし，本体はりオンKKK依頼 してリオンAA 34 ISO 用飞改装したAA 34 オージ オメータを, 受話器飞は ISO 用として最も一般的飞 用いられている TDH 39 (Telephonics 社製)を使用 した。

\section{検查, 方式}

日本オージオロジー学会の勧める方式に従い，上昇 法汇より $1 \mathrm{~dB}$ ステッップ読みで，きこ壳のレベル (Hearing Threshold Level の対応邦語がないため本 論中で便宜的飞使用)を求めた。検查音海秒 2 回 衝撃係数50\%の断続音を用いた。検查前にアンケート 用紙記入などの作業を行なわせ，検查に入る前化その 検查場で少なくとも 30 分以上休息をとらせた後に検查 を行ない, バス，乘用車なビの騷音沉よるTTSの影 就加ら逃れた。

読みの記入は，各周波数とも信号匹なれて，ほとん ど同じ值を安定して忘答するよようになってから行な った。上昇法の䛷みの計 5 '回の記入と共汇下降法の読 みもそれぞれ 5 回記入し, 㥛限法の成樍を求めるため の資料とした。

\section{検 查 成 績}

\section{［I］無騷音地区}

(1) 岩手県宮古甫郊外津軽石地区

i) 1972 年度, 被検者総数 83 名, 万ち有効数 77 名 154 聶, 男性 9 名, 女性 68 名 136 耳である。 男性群は検查対自数が少ないため省略した。

表 1 は，女性群阔耳の各周波数のきこえのレベルの 平均と, 年齢との間の相関係数表, 図 1 は, 右耳のそ れぞれの周波数の低下傾向を, 図 2 㹥, 左耳低下傾 向を示したものである。

相関係数は最大で右耳 $2,000 \mathrm{~Hz}$ で一0. 1951, 次いで 右耳 $8,000 \mathrm{~Hz}$ で 0.1691 であり, 特飞年齢との相関は 認め官れなかった。8,000 Hz のみは, 左耳も $\mathrm{r}=0.1179$ を示し，両耳とを此較的低下傾向が認められたが， 年龄との間汇相関があるとは雲光ない。

ii) 1974 年度, 被検者総数 68 名, 万ち男性 15 名 30 耳, 女性53名 106 耳である。

男性群は検査詨象数が少ないため省略した。 
表'1 岩手県宮古市津軽石地区住民純音聴力の相関係数表

1972年度 女 性 $N=68$

\begin{tabular}{|c|c|c|c|c|c|c|c|c|}
\hline 耳 周波数 $\mathrm{Hz}$ & 250 & 500 & 1,000 & 2,000 & 3,000 & 4,000 & 6,000 & 8,000 \\
\hline 侧 & 0.3085 & 0.0512 & 0.0937 & -0.1951 & -0.1093 & 0.0471 & -0.0239 & 0.1691 \\
\hline 右 & 0.1487 & 0.1675 & 0.0239 & -0.0467 & -0.0044 & -0.0023 & 0.0685 & 0.1179 \\
\hline
\end{tabular}

表 2 岩手県宮古本津軽石地区住民純音呫力の相関係数表 1974年度 女 性 $N=53$

\begin{tabular}{|c|c|c|c|c|c|c|c|c|}
\hline 耳周渡数 $\mathrm{Hz}$ & 250 & 500 & 1,000 & 2,000 & 3,000 & 4,000 & 6,000 & 8,000 \\
\hline 右 & 0.1201 & 0.1762 & 0.1234 & 0.0039 & 0.0652 & -0.0413 & -0.0763 & -0.0272 \\
\hline 左 & 0.1157 & 0.2092 & 0.2689 & 0.0320 & -0.0999 & -0.0841 & -0.0566 & -0.0410 \\
\hline
\end{tabular}

表 3 岩手県宮古市津軽石地区住民純音聴力の相関係数表 1975年度 女 性 $N=56$

\begin{tabular}{|c|c|c|c|c|c|c|c|c|}
\hline 聚 側 & 250 & 500 & 1,000 & 2,000 & 3,000 & 4,000 & 6,000 & \multicolumn{1}{c|}{8,000} \\
\hline 右 & 0.1053 & -0.1087 & -0.1254 & -0.2268 & -0.1367 & 0.0735 & 0.2365 & -0.0424 \\
\hline 左 & -0.0398 & 0.1862 & 0.0268 & 0.1774 & 0.0412 & 0.2911 & 0.3093 & 0.2088 \\
\hline
\end{tabular}

表 4 岩手県宮古市津軽石地区住民純音聴力の相関係数表 $1972 ， 1974 ， 1975$ 年度 男 性 $\mathrm{N}=30$

\begin{tabular}{|c|c|c|c|c|c|c|c|c|}
\hline 耳周波数 $\mathrm{Hz}$ & 250 & 500 & 1,000 & 2,000 & 3,000 & 4,000 & 6,000 & 8,000 \\
\hline 右 & -0.1307 & -0.1075 & -0.2635 & 0.0897 & 0.1279 & -0.0398 & 0.0888 & 0.2085 \\
\hline 左 & 0.1804 & 0.1914 & 0.2153 & 0.2131 & 0.1642 & 0.3255 & 0.2428 & 0.3416 \\
\hline
\end{tabular}

表 5 岩手県宮古方津軽石地区住民純音聴力の相関係数表

1972，1974，1975年 女 性 $N=177$

\begin{tabular}{|c|c|c|c|c|c|c|c|c|}
\hline 洫側 & 250 & 500 & 1,000 & 2,000 & 3,000 & 4,000 & 6,000 & 8,000 \\
\hline 右 & 0.1425 & 0.0425 & 0.0620 & -0.1160 & -0.0407 & -0.0145 & -0.0132 & -0.0294 \\
\hline 左 & 0.0554 & 0.1397 & 0.1022 & 0.0455 & -0.0180 & 0.0730 & 0.1065 & 0.0406 \\
\hline
\end{tabular}

表 2 は，女性群両耳の各周波数のきこえと年齿との 間の相関係数表である。図 3 は, 同群右耳のきこえの 低下傾向の年齢的推移を示したものであり, 図4は, 同群左耳のものである。 相関係数は $2,000 \mathrm{~Hz}$ 以上はいずれも 0.1 以下であ
り，小さな值を示しているので，環境騒音による影響 は無いと考光られる。

iii） 1975年度

被検者総数 62 名, 124 耳, 男性 6 名 12 耳, 女性 56 名 112 耳, 男性 6 名注数であり, 此較検討の対象たり 


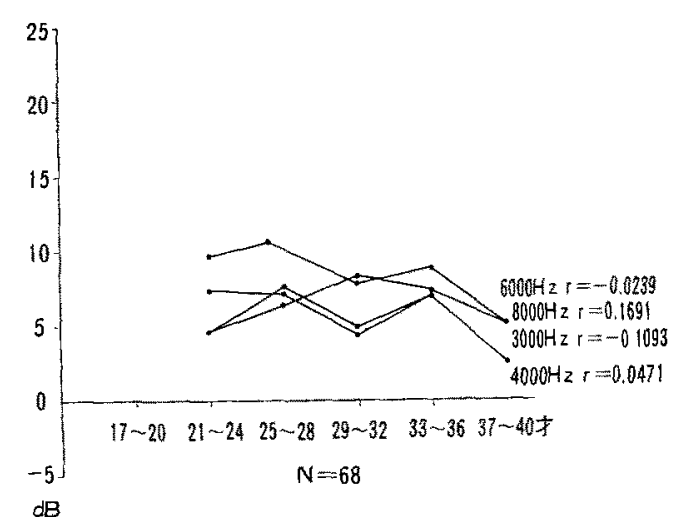

図 1 岩手県宫古市津軽石地区住民の純音聴 力平均值 1972年度 女徃 右耳

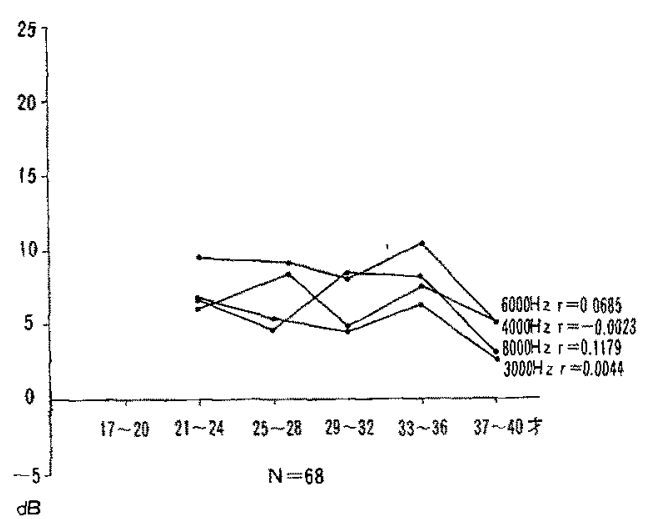

図 2 岩手県宫古市津軽石地区住民の純音聴 力平均值 1972年度 交性 左耳

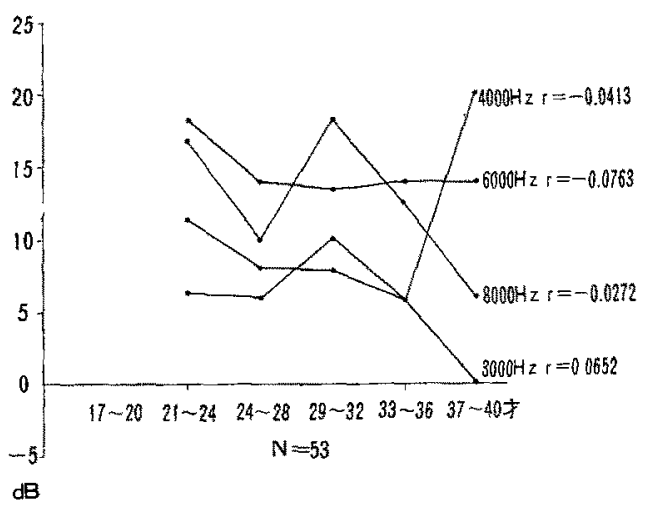

図 3 岩手目宮古市津軽石地区住民の純音㯖 力平均值 1974年度 女性 右耳

えないので，省略する。

表 3 は，両耳の年粭とさこえのレベルとの間の相関 係数表である。図 5 は，右耳の 4 年ごと汇わけたグル
ヒプのきこえの平均值の推移であり，図6は，左其の それを示している。

右耳 $6,000 \mathrm{~Hz}$ k招いて, $\mathrm{r}=0.2365$, 左耳 $4,000 \mathrm{~Hz}$, $r=0.2911,6,000 \mathrm{~Hz}, r=0.3093$ とやや畗い值を示し ている点が，同地域の他年度調㮅成續と異った点であ る。

iv）年度别に分けずにこの漁利地带を1グループと して検討した成続は次の通りである。

被検者総数 213 名, 万占有效数 207 名, 414 耳, 男 经30名60耳，女性 177 名 354 耳である。

(亿) 男性群

表 4 は, 画耳のきこえと作龄との間の相関係数表で ある。

图 7 牥，4年ごとにグループ分けた右耳のきこえの 平均值の推移であり，図8估，左耳のそれを示している。

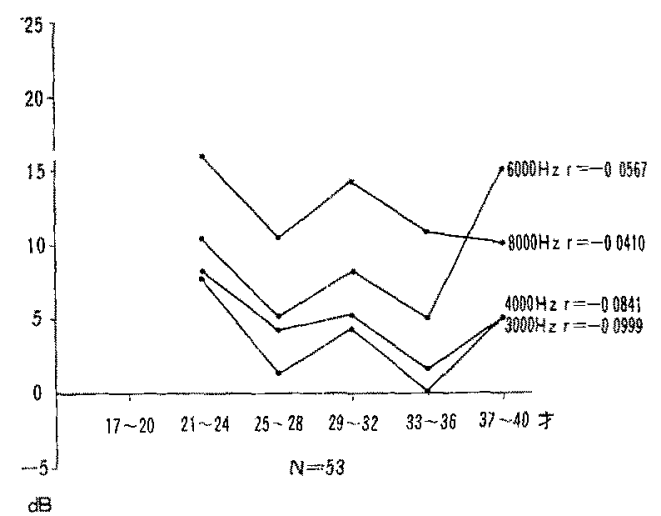

図4 岩手泉宮古市渄柽石地区住民口純音聴 力平均值 1974年度 女性 左耳

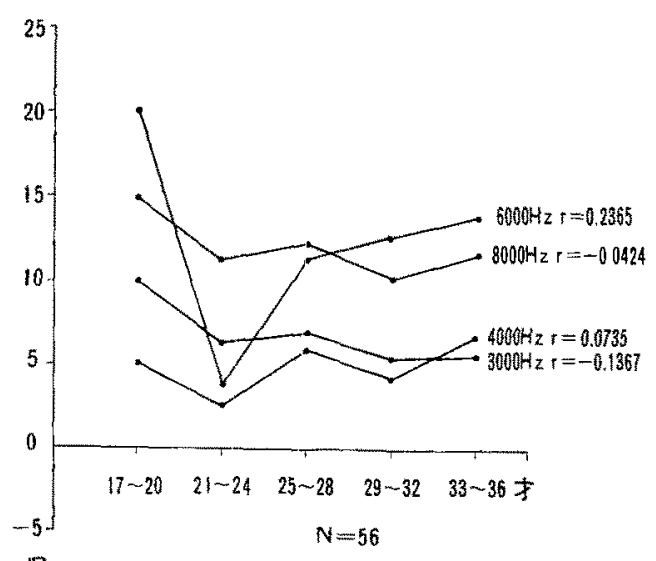

図 5 岩手目営古市津軽石地区住民の純音聴 力平约值 1975年度 女性 右耳 


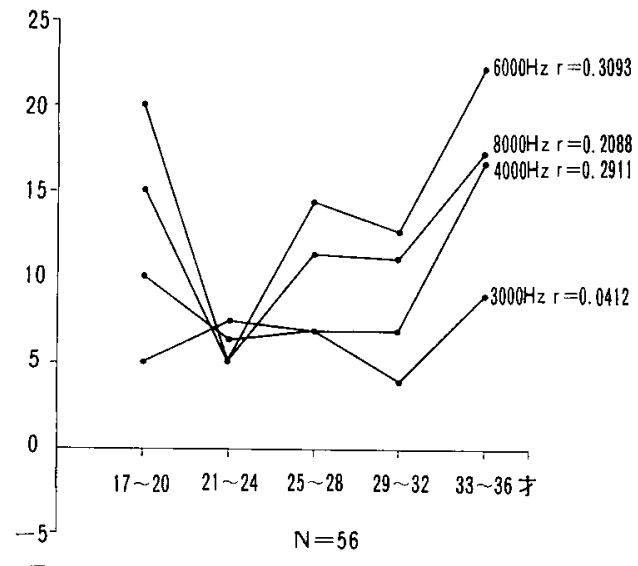

$\mathrm{dB}$

図 6 岩手県宮古市津軽石地区住民の純音聴 力平均值 1975 年度 女性 左耳

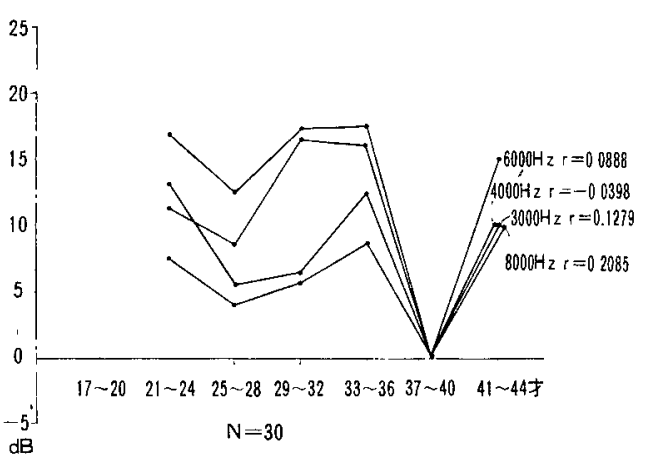

図 7 岩手県宮古市津軽石地区住民の緢音聴力平 均値 $1972,1974,1975$ 年度 男性 有耳

相関係数は, 右耳 $8,000 \mathrm{~Hz}$ が $\mathrm{r}=0.2085$, 左耳 $2,000 \mathrm{~Hz} r=0.2131,4,000 \mathrm{~Hz} r=0,3255,6,000 \mathrm{~Hz}$ $r=0.2428,8,000 \mathrm{~Hz} \quad r=0.3416$ が高值を示してい る。

(口) 女性群

表 5 は，両耳のきこえと年龄との間の相関係数表で ある。

図 9 は，4年ごとにグループにわけた右耳のきこえ の平均値の推移であり，図10は，左耳のそれである。 相関係数よりみると，いずれあ低値であり年齢層の 分布のバランスもよく, 無騒音地域の傾向を明瞭に示 しているように思われる。

(2) 岩手県宮古市郊外花輪地区

i） 1972年度，被検者総数83名 166 耳，万ち男性江 22 名 44 耳，女性61名 122 耳である。

表 6 は, 男性両耳のきこ党と年齢との相関係数表で

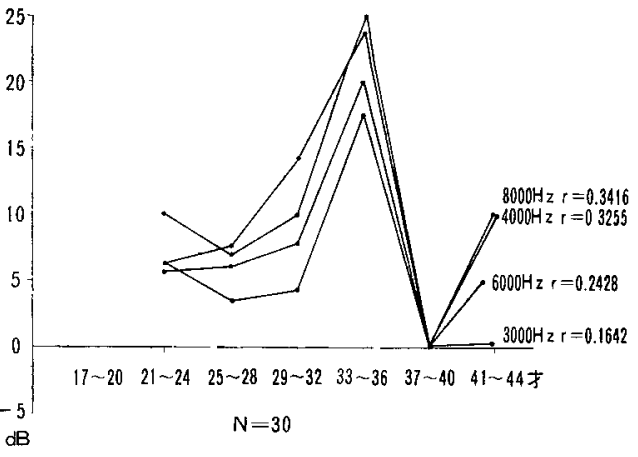

図 8 岩手県宮古市津軽石地区住民の純音聴力平 均值 $1972,1974,1975$ 年度 男性 左耳

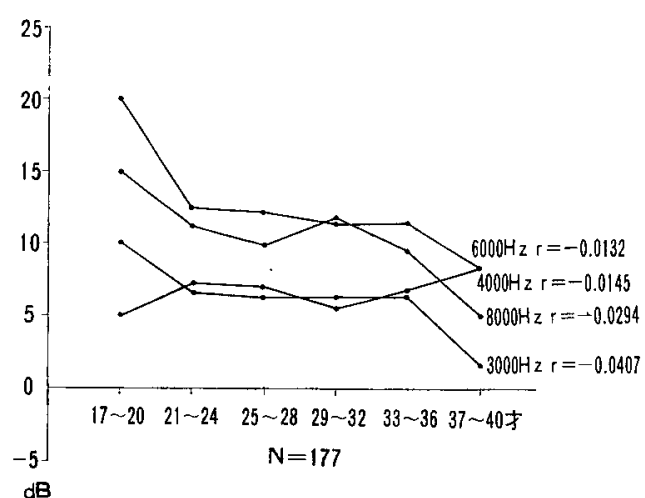

図 9 岩手県宮古市津軽石地区住民の純音聴力平 均値 1972，1974，1975年度 女性 右耳

ある。

図11は，4年ごとにグループにわけた右耳のきこえ の平均值の推移であり，図12は，左耳のものである。

男性群に沶いては，無騒音地域であるにもかかわら ず，明らか騒音難聴群と考えられる傾问が，相関係 数法よび平均值の推移より認められる。特に右耳 $4,000 \mathrm{~Hz} r=0.3968$, 左耳 $4,000 \mathrm{~Hz} r=0.4040$ は左 右対称性で高值であり，各年齢層の人数が平均してい るため, 注目に值する。この高い值に対しては後で検 討を加える。

表 7 は，同群女性両耳のきこえと年齢との相関係数 表である。

図13は，4 年ごとルグループKわけた右耳のきこえ の平均值の推移であり，図14は，左耳のものである。 女性群については, 同様に右耳 $3,000 \mathrm{~Hz}, 4,000 \mathrm{~Hz}$ に离值が恋められた。 
表 6 岩手圎宮古市郊外花輪地区住民純音聴力の相関係数表

1972年度 男. 性 $\mathrm{N}=22$

\begin{tabular}{|c|c|c|c|c|c|c|c|c|}
\hline 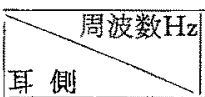 & 250 & 500 & 1,000 & 2,000 & 3,000 & 4,000 & 6,000 & 8,000 \\
\hline 右 & -0.1806 & -0.2148 & -0.1485 & 0.0592 . & 0.2019 & $0.396 \varepsilon_{i}$ & 0.1962 & -0.1405 \\
\hline 左 & -0.1487 & -0.1743 & -0.0599 & -0.0159 & 0.2804 & 0.4040 & 0.2291 & 0.1365 \\
\hline
\end{tabular}

表 7 岩手目宮古市郊外化輪地区住民純音㯖力の相関係数表

1972年度 女性 $N=61$

\begin{tabular}{|c|c|c|c|c|c|c|c|c|}
\hline 耳 周波数 $\mathrm{Hz}$ & 250 & 500 & 1,000 & 2,000 & 3,000 & 4,000 & 6,000 & 8,000 \\
\hline 右 & 0.2158 & 0.0541 & 0.2465 & 0.0447 & 0.2915 & 0.2511 & -0.1137 & 0.0554 \\
\hline 左 & 0.2226 & 0.3417 & 0.2305 & 0.1802 & 0.2179 & 0.1843 & 0.1087 & 0.1537 \\
\hline
\end{tabular}

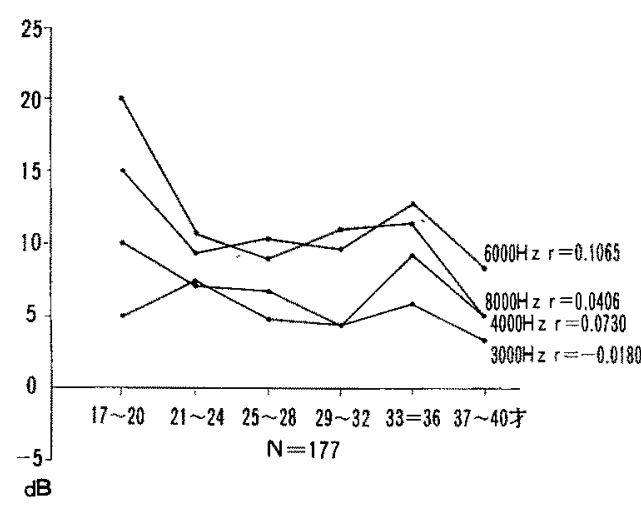

図10 咭手県宮古市津鞋石地区住民の純音聴力平 均㑤 $1972,1974,1975$ 年度 女性 左耳

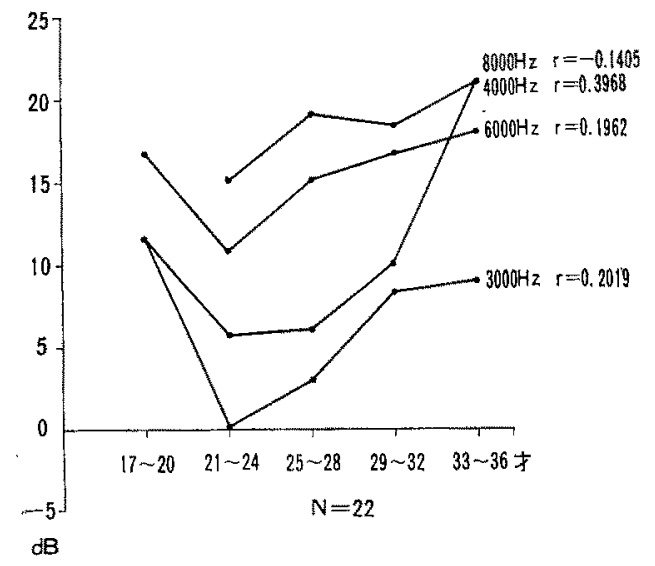

図11 岩手県宮古市郊外花輪地区住民の純音 聴力平均值 1972 年度 男性 右耳

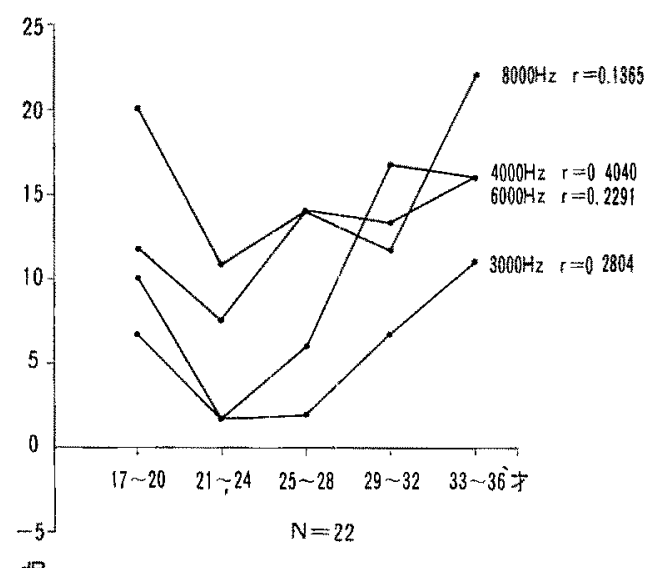

図12 岩手県宫古市郊外花輪地区住民の緃音 聴力平均值 1972年度 男性 左耳

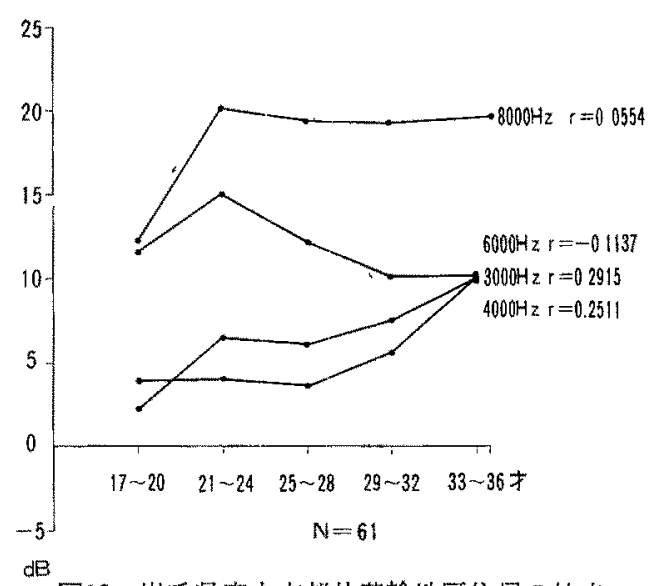

図13岩手県棠古市郊外花輪地区住民の純音 聴力平均值 1972年度 女性 在耳 


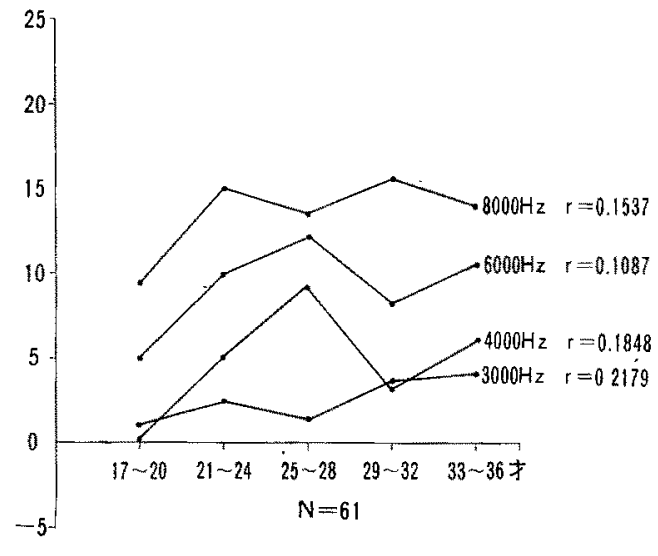

図14 岩手県宮古市郊外花傮地区住是の純竟 聴力平均値，1972年度，女性 左耳

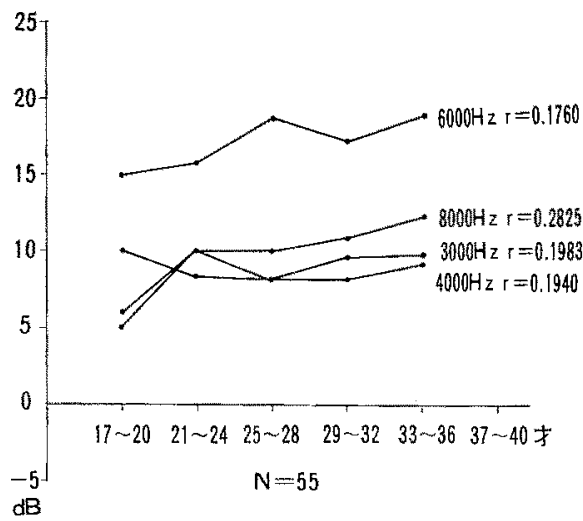

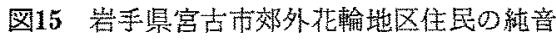
聴力平均值 1974年度 女性 右耳

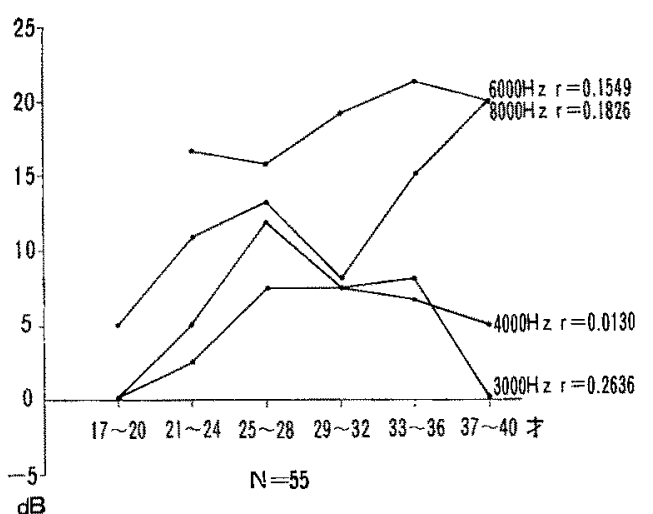

図16 岩手敇宫古市郊外花輪地区住民の純音 聴力平均値 1974年度 女性 左耳

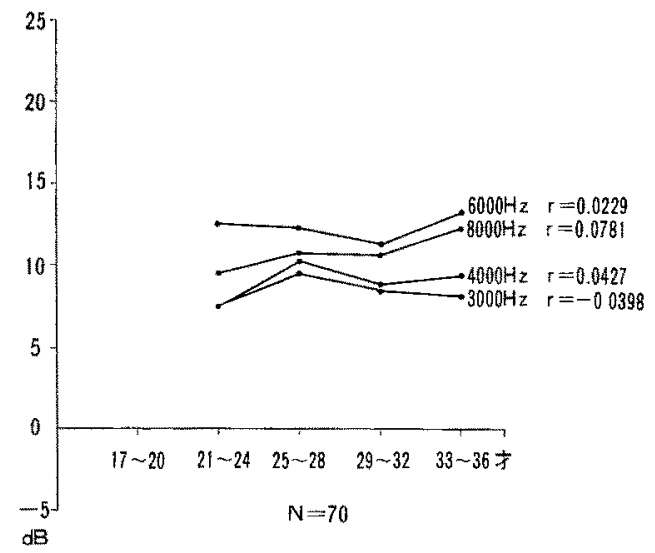

図17 岩手罢宫古市郊外花輸地区住民の純音 聴力平均值 1975年度 女性 右耳

麦 8 岩手県宮吉市郊外花輸地区住民純音聴力の相関係数表

1974年度 女 性 $N=55$

\begin{tabular}{|c|c|c|c|c|c|c|c|c|}
\hline 耳 周波数 $\mathrm{Hz}$ & 250 & 500 & 1,000 & 2,000 & 3,000 & 4,000 & 6,000 & 8,000 \\
\hline 在 & 0.1959 & 0.1725 & 0.2453 & 0.1598 & 0.1983 & 0.1940 & 0.1760 & 0.2825 \\
\hline 左 & -0.0993 & -0.0178 & 0.1520 & 0.1332 & 0.2636 & 0.0130 & 0.1549 & 0.1826 \\
\hline
\end{tabular}

表 9 岩手県宮古市郊外花輪地区住民純音聴力の相関係数表 1975年度 女 性 $N=70$

\begin{tabular}{|c|c|c|c|c|c|c|c|c|}
\hline 耳 周波数 $\mathrm{Hz}$ & 250 & 500 & 1,000 & 2,000 & 3,000 & 4,000 & 6,000 & 8,000 \\
\hline 右 & 0.1028 & 0.0546 & -0.0257 & 0.0308 & -0.0398 & 0.0427 & 0.0229 & 0.0781 \\
\hline 左 & -0.0633 & -0.0854 & -0.0981 & -0.0912 & -0.0088 & 0.0349 & 0.0946 & 0.0423 \\
\hline
\end{tabular}


ii） 1974 年度, 被㭘者総数55名 110 耳, 対象者は全 員女性である。

表 8 は, 雨耳のきこえと年龄との間の相関係数表で ある。図15は，4年ごとにグループに分けた右耳のき こえの平均值の推移を示し，図16は，左耳のそれを示 している。

相関係数は, 右耳 $8,000 \mathrm{~Hz} r=0.2825$, 左耳 3,000 $\mathrm{Hz} r=0.2636$, と一部此較的高値を示しているが, 概 して低く，男性群との間に㟟いがあるように思われ る。

iii）1975年度，被検者総数 72 名 144 耳，万号男性 2 名，女性70名で，男性は少数のため省略する。

表 9 は，雨耳のきこえと年齢との間の相関係数表で ある。

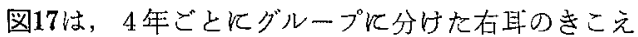
の平均值の推移を示したもので, 図18は, 左耳のそれ である。

相関係数は，いずれの周波数に扔いてもほとんど 0 汇近く，相関は全くないと考学られる。

iv）年度別飞分けず，花輪地区全員についての検討 を試みた。被検者総数 210 名, 万ち男性 24 名, 女性 186名であった。

(1) 男性群

表10は，その両耳のきこえと年齢との間の相関係数 表である。

図19は，4年ごとにグループに分けた右耳のきこえ の平均值の推移であり, 図20は, 左耳゙企れである。 相関係数は右耳, $3,000 \mathrm{~Hz} \quad \mathrm{r}=0.2627,4,000 \mathrm{~Hz}$ $\mathrm{r}=0.4616,6,000 \mathrm{~Hz} \mathrm{r}=0.2739$, 左耳 $3,000 \mathrm{~Hz} r=$
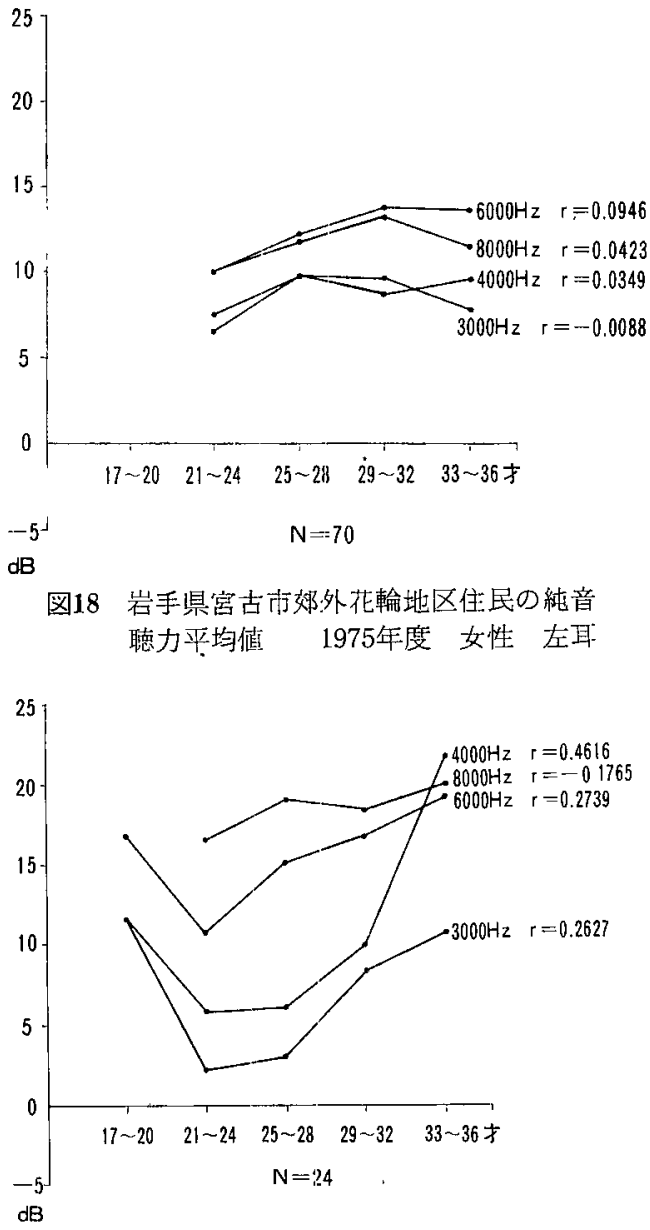

図19 岩手県宮古方郊外花輪地区住民の純音德力 平均值 $1972,19^{\prime} 74,1975$ 年度 男性 石耳

表 10 岩手県宮古市郊外花輪地区住民純音聴力の相関係数表

1972，1974，1975年度 男 性 $\mathrm{N}=24$

\begin{tabular}{|c|c|c|c|c|c|c|c|c|}
\hline 耳 周波数 $\mathrm{Hz}$ & 250 & 500 & 1,000 & 2,000 & 3,000 & 4,000 & 6.000 & 8.000 \\
\hline 側 & -0.1723 & -0.1130 & -0.1237 & 0.0496 & 0.2627 & 0.4616 & 0.2739 & -0.1765 \\
\hline 右 & -0.0938 & -0.0753 & -0.0293 & 0.0096 & 0.3349 & 0.4641 & 0.2774 & 0.1280 \\
\hline
\end{tabular}

表 11 岩手県宮古市郊外北輪地区住民純音聴力の相関係数表

1972，1974，1975年度 女 性 $\mathrm{N}=186$

\begin{tabular}{|c|c|c|c|c|c|c|c|c|}
\hline 固波数 $\mathrm{Hz}$ & 250 & 500 & 1,000 & 2,000 & 3,000 & 4,000 & 6,000 & 8,000 \\
\hline 右 & 0.1194 & 0.1480 & 0.1474 & 0.1240 & 0.1867 & 0.1935 & 0.0975 & 0.0512 \\
\hline 左 & -0.0754 & -0.0115 & 0.0480 & 0.1026 & 0.1774 & 0.1099 & 0.2117 & 0.1009 \\
\hline
\end{tabular}


$0.3349,4,000 \mathrm{~Hz} \quad \mathrm{r}=0.4641,6,000 \mathrm{~Hz} \quad \mathrm{r}=0.2774 \mathrm{ks}$ 高值である。

(a) 女性群

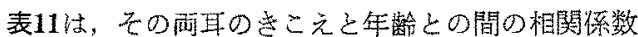
㤗である。

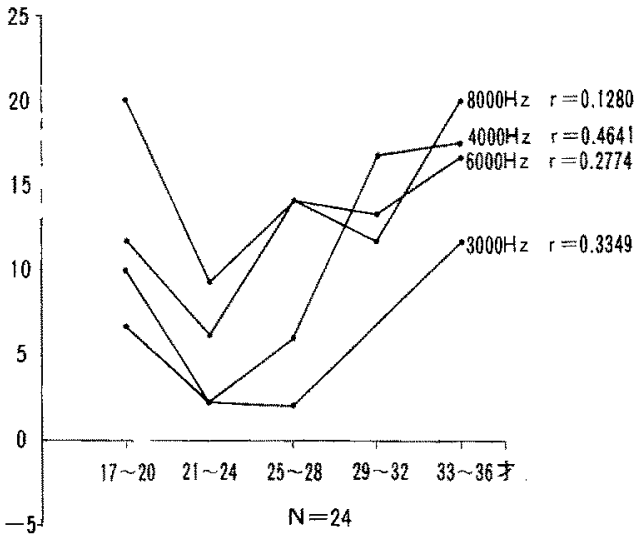

$\mathrm{dB}$

图20吉手県宫古市郊外花輪地区住民の純音悖力 平均值 $1972,1974,1975$ 年度 男性 左耳

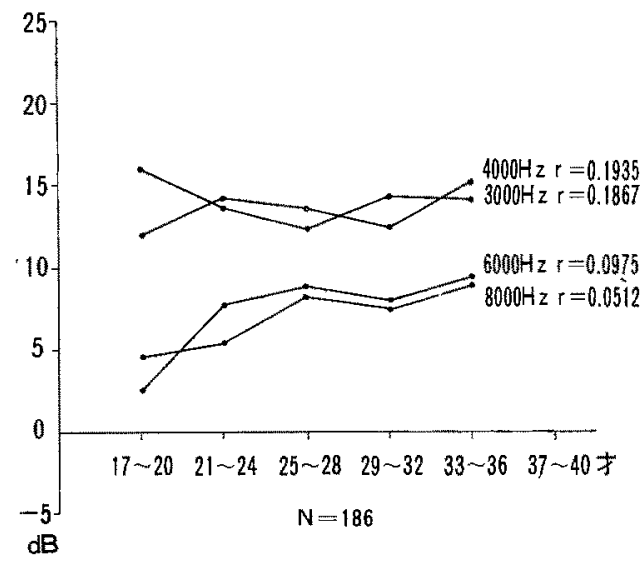

図21岩手県宮古市郊外花輪地区住民の純音衈力 平均值 1972,1974, 1975年度 女性 右耳
授境騒音の純音聴力への影響調查について 235

図21は，4年ごとのグループKわけた在其のきこえ の平均值の推移であり，図22は，左耳のそれである。 相関係数は右耳 $3,000 \mathrm{~Hz}, 4,000 \mathrm{~Hz}$ の犆が $0.2 \mathrm{~K}$ 近ずいていること, 左耳 $3,000 \mathrm{~Hz}$ が $\mathrm{r}=0.1774$, $6,000 \mathrm{~Hz} r=0.2117$ が高嗔であること以外，特飞高值 寺示すのはなかった。

$8,000 \mathrm{~Hz}$ の相関係数の低い点は特猉的である。

（3）栃木県那須郡小川町片平地区

i) 1975年度

無騒音地域の一つとして調疽した山村の農村地帯の 人達，36名72耳を対象としている。対象は全員女性で ある。

表12は、両耳のきこえと年龄との相関係数表である。 図23は，右耳の4年ごとに分けられたグループのきこ えの平均値の推移であり，図24は，左耳のそれである。

この調查成續は対象数が少なく，また年齢的に30歳 以上の対象数吕 6 名 $17 \%$ 之兵愺県伊丹地区之逆の分行 を示しているため，相関係数はこのまま参洘にしえな い感もあるが, 平均値よりみると, 相関係数との間に 离い関連性も諗められるので，何らかの原因を考虑す る必要加あると思われる。

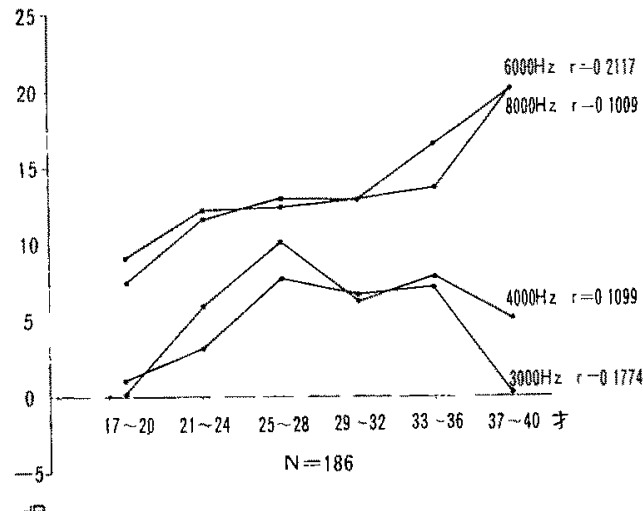

図22 岩手県宮古南郊外花輪地区住民の純音聴力 平均值 $1972,1974,1975$ 年度 女性 左耳

表 12 栃水県那須郡小川町片平地区住民純音聴力の相関係数表 女 性 $\mathrm{N}=36$

\begin{tabular}{|c|c|c|c|c|c|c|c|c|}
\hline 国側 & 250 & 500 & 1,000 & 2,000 & 3,000 & 4,000 & 6,000 & 8,000 \\
\hline 右 & 0.2088 & 0.1278 & 0.2809 & 0.3962 & 0.3912 & 0.5792 & 0.3854 & 0.2829 \\
\hline 左 & 0.2276 & 0.2783 & 0.2032 & 0.5855 & 0.4356 & 0.3556 & 0.3277 & 0.1340 \\
\hline
\end{tabular}




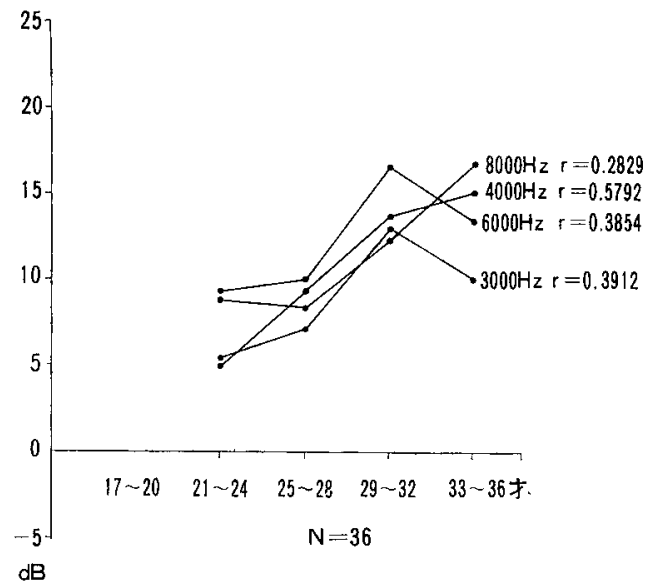

図23栃木県那須郡小川町片平地区住民至純 音聴力平均值 1975 年度 女性 右耳

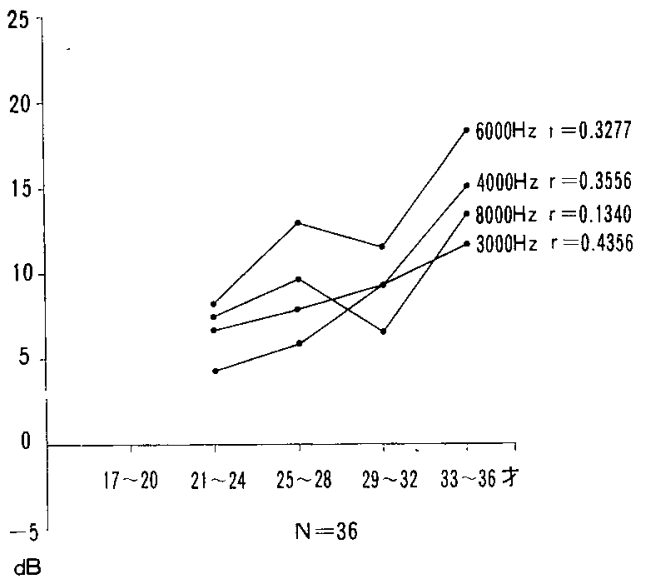

図24 栃木県那須郡小川町片平地区住民の純 音㯖力平均值 1975 年度 女性 左耳
特左耳 $2,000 \mathrm{~Hz} \mathrm{r}=0.5855,3,000 \mathrm{~Hz} r=0.4356$, $4,000 \mathrm{~Hz} \mathrm{r}=0.3556$ は異常な高さと考えられる。

(4) 山形県寒河江市大江地区

この地域は無騒音地域として取り上げたが，検查対 象は中学生, 高校生の若年層とした。

被検者総数は 114 名 228 耳で, 男性 59 名 118 耳，女 性55名 110 耳である。

(イ) 男性群

表13は，きこえと年榆との間の両耷の相関係数表で ある。

図25は，4年ごとにグループに分けたきこえの右耳 の平均值の推移を示したもので，図26は，左耳のそれ である。

相関係数は男性群では, 右耳 $4,000 \mathrm{~Hz} \quad \mathrm{r}=0,2362$ を認めたが，平均值の推移からは特に低下の傾向はな いと考光られる。

(口) 女性群

表14は，きこえと年齢との間の雨耳の相関係数表で ある。

図27は,4年ごとに.グループに分けたきこえの右耳の 推移を示したものであり, 図28は, 左耳のそれである。 女性群では右耳 $2,000 \mathrm{~Hz} \mathrm{r}=0.3636,3,000 \mathrm{~Hz}$ r= $0.3473,4,000 \mathrm{~Hz} r=0.3328$ が高值であるが, 平均值 よりみて，4,000 Hz とのみ若干低下傾向を認めた。 左耳 $6,000 \mathrm{~Hz} \mathrm{r}=0.3020$ 扰よび $8,000 \mathrm{~Hz} \quad \mathrm{r}=0.4366$ あ平均の推移から低下傾向があるよう江思われた。

(5) 和歌山県那賀郡那賀町地区

i) 1976 年度

近畿地方の敘騒音地域として調查した純農村地带で

表 13 山形県寒河江市大江地区住民純音觔力の相関係数表 1972年度 男 性 $N=59$

\begin{tabular}{|c|c|c|c|c|c|c|c|c|}
\hline 耳 㑡 & 250 & 500 & 1,000 & 2,000 & 3,000 & 4,000 & 6,000 & 8,000 \\
\hline 右 & 0.0876 & 0.0469 & -0.1473 & -0.0329 & -0.0091 & 0.2362 & 0.1096 & 0.1154 \\
\hline 左 & -0.0339 & -0.0237 & -0.1814 & 0.0559 & -0.0147 & 0.0657 & $\overline{-0} .1840$ & -0.0259 \\
\hline
\end{tabular}

表 14 山形県寒河江市大江地区住民純音聴力の相関係数表

1972年度 女 性 $\mathrm{N}=55$

\begin{tabular}{|c|c|c|c|c|c|c|c|c|}
\hline 目波数 $\mathrm{Hz}$ & 250 & 500 & 1,000 & 2,000 & 3,000 & 4,000 & 6,000 & 8,000 \\
\hline 右 & 0.1275 & 0,2123 & 0.0798 & 0.3636 & 0.3473 & 0.3328 & 0.2528 & 0.2799 \\
\hline 左 & 0.3985 & 0.3208 & 0.0670 & 0.2717 & 0.0967 & 0.2609 & 0.3020 & 0.4366 \\
\hline
\end{tabular}




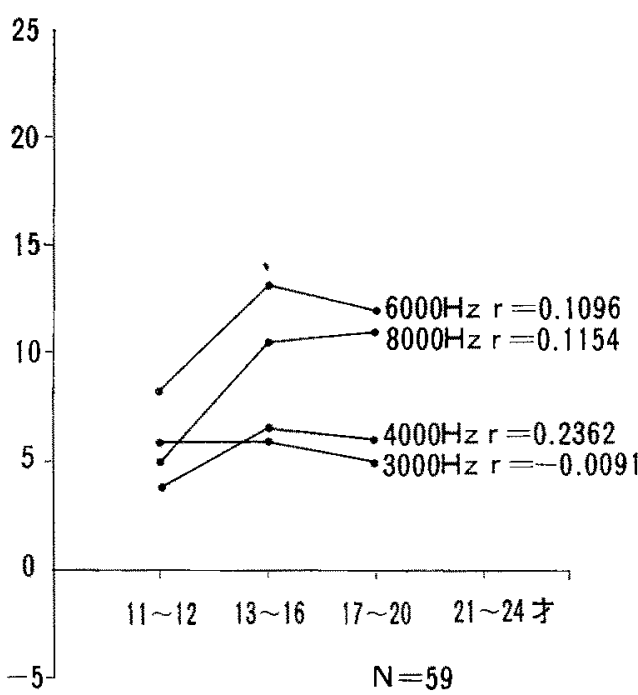

$\mathrm{dB}$

図25山形県寒河江市大江地区住民の純音㯖 力平均值 1972年度 男性 右耳

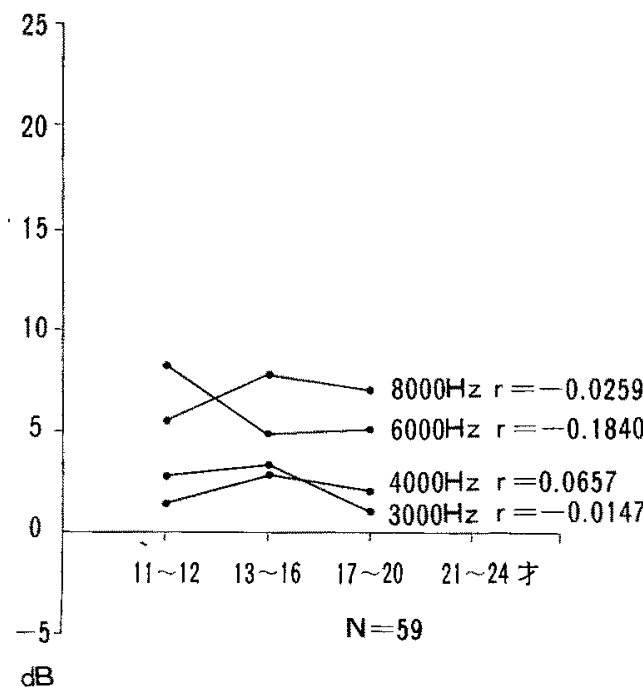

図26山形県寒河江官大江地区住民の純音德 力平均値一1972年度 男性 左耳

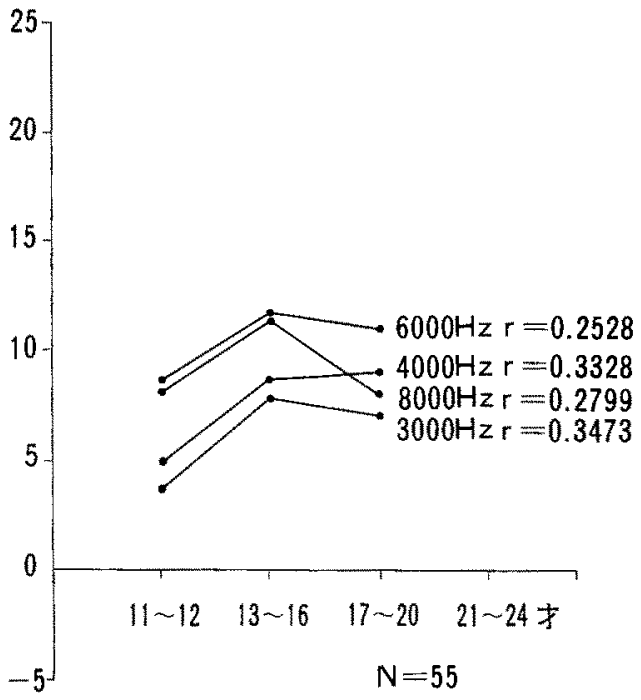

dB.

図27山形罢寒河江市大江地区住民の綎音聴 力平均值 1972年度 女性 右耳

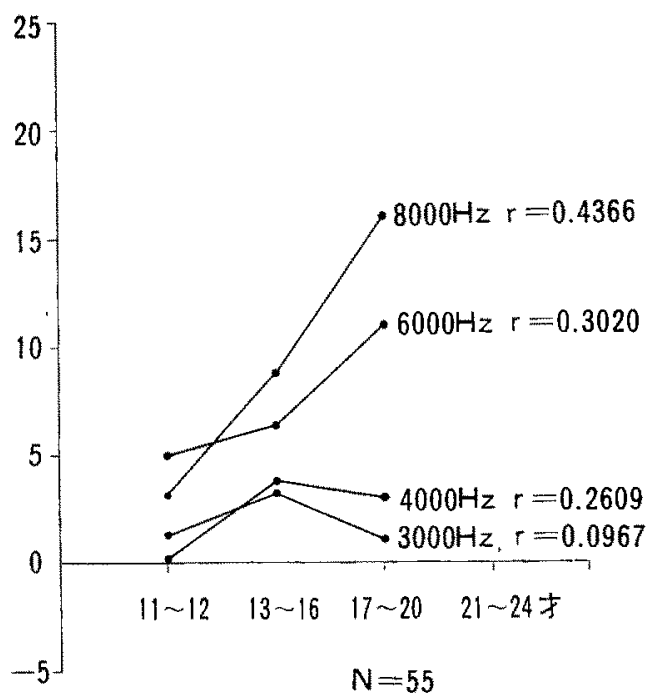

dB

図28山形目寒河江市大江地区住民の絬音聴 力平均值 1972年度 女性 左耳

表 15 和歌山県那賀郡那賀町地区住民純音聴力口相関係数表

1976年度 男 性 $N=67$

\begin{tabular}{|c|c|c|c|c|c|c|c|c|}
\hline 洫周波数 $\mathrm{Hz}$ & 250 & 500 & 1,000 & 2,000 & 3,000 & 4,000 & 6,000 & 8,000 \\
\hline 右 & 0.0634 & 0.1016 & 0.2611 & 0.4190 & 0,2781 & 0.2450 & 0.4159 & 0.3164 \\
\hline 左 & 0.0832 & 0.1283 & 0.2784 & 0.3729 & 0.2180 & 0.0973 & 0.2242 & 0.3239 \\
\hline
\end{tabular}


ある。

被検者総数 122 名 144 耳，万ち男性 67 名 134 耳，女 性55名 110 耳である。

(1) 男性群

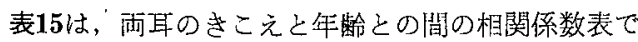
ある。

図29は，4年ごとにグループK分けた右耳のきこ光 の平均值の推移であり，図 30 は，左耳のそれを示し ている。

相関係数は右耳 $3,000 \mathrm{~Hz} \mathrm{r}=0.2781,4,000 \mathrm{~Hz} \mathrm{r}=$ $0.2450,6,000 \mathrm{~Hz} \mathrm{r}=0,4159,8,000 \mathrm{~Hz} \mathrm{r}=0,3164$, 左耳: $3,000 \mathrm{~Hz} \quad \mathrm{r}=0.2180,6,000 \mathrm{~Hz} \quad \mathrm{r}=0.2242$, $8,000 \mathrm{~Hz} r=0.3239$ と高值を示している。このような 高值を示すグループは，著者らの経験によれば，純農 村地帯では前述の杤木県那須郡小川町片平地区の女性 群，ならびそ職業性感音難㯖例群である。航空機運航 乗員，地下鉄乗務買，録音技術者のグループであり， この高值出現の理由は不明であるる。

\section{(口) 女性群}

表16は，両耳のきこえと年龄との間の相関係数表で ある。

図31は，4年ごとにグループに分けた右耳のきこえ の平均値の推移を示し，図32は，左耳のそれを示して いる。

相関係数は右耳 $6,000 \mathrm{~Hz} r=0.2112$ が高值を示し ている以外，特飞高值を示すものはなかった。

[II] 有騒音地区

(1) 東京都江戸川区地区

i） 1974年度, 被榆者総数 101 名 202 耳, 万ち男性 72名144耳, 女性29名54耳である。

表17は，男性群両耳の年齢ときこえのレベルの間の 相関係数表である。

図33は，各 4 年ごとに分けたグループの右耳のこ えの平均值の推移を示し, 図34は, 左耳のそれを示し ている。

表18は，女性群両耳の相関係数表である。

図35は, 各 4 年ごとにグループ分けた右耳の平均值 の推移を示し，図36は，左耳のそれを示している。

男性群の相関係数は $2,000 \mathrm{~Hz}$ 以上飞特いても比較 的高値を示し, 右耳 $2,000 \mathrm{~Hz} r=0.2797,4,000 \mathrm{~Hz}$ $\mathrm{r}=0.2815,6,000 \mathrm{~Hz} \mathrm{r}=0.3107,8,000 \mathrm{~Hz} \mathrm{r}=0.2702$ であり,左耳 $2,000 \mathrm{~Hz} r=0.3053,3,000 \mathrm{~Hz} r=0.2697$ であった。

これK対して女性群は例数は29例と比較的少ないの
で直ちに比較検討はできないが，相関係数は男性群に 比べて低く, 最高は左耳 $8,000 \mathrm{~Hz} r=0.2981$ であっ た。

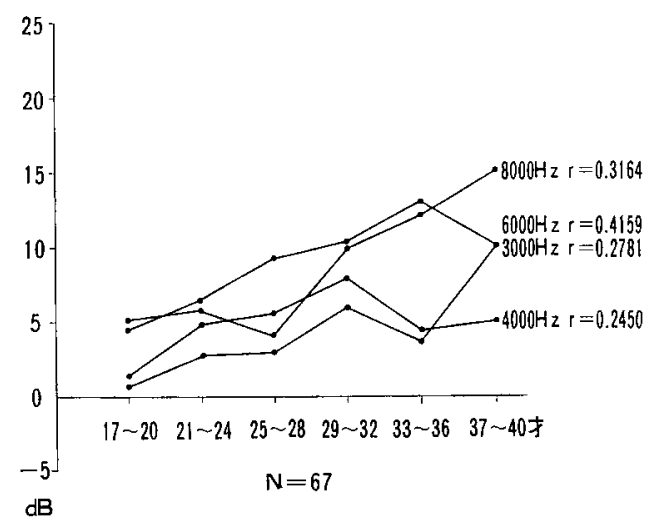

図29 和歌山県那賀郡那賀町地区住民の純音 聴力平均值 1976年度 男性 石耳

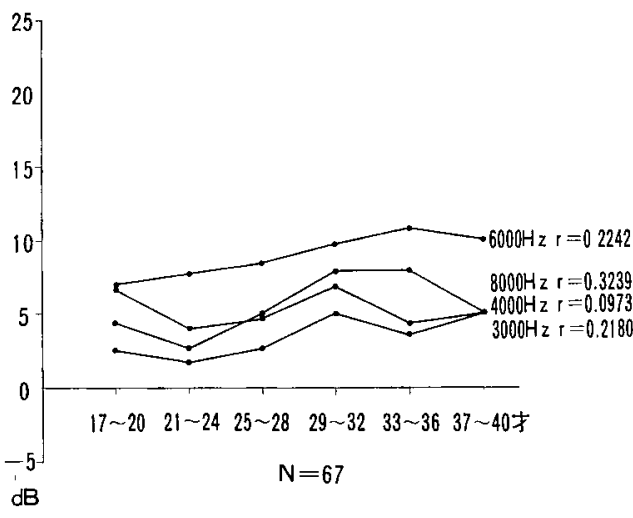

図30 和歌山県那賀郡那賀町地区住民の純音 聴力平均值 1976年度 男性 左耳:

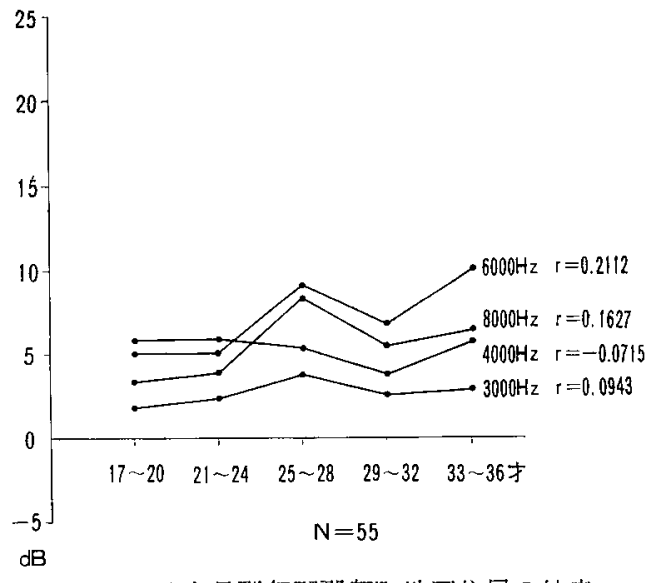

図31 和歌山県那賀郡那賀町地区住民の.純音 聴力平均值 1976年度 女性 右耳 


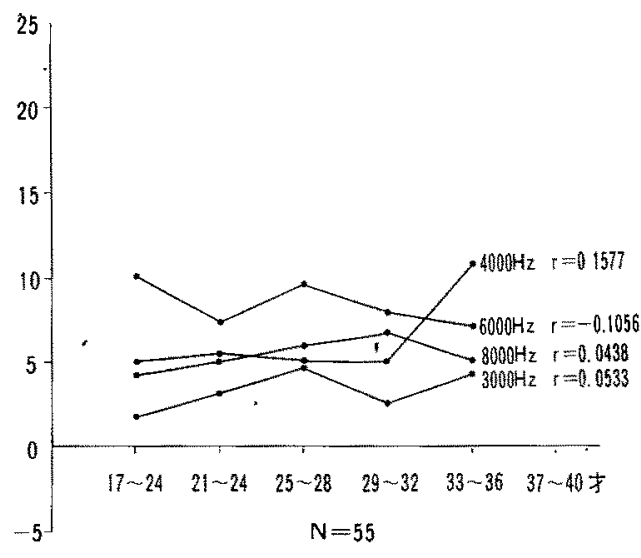

$\mathrm{dB}$

図32 和歌山県那賀郡那賀町地区住民の純音 聴力平均㥁 1976 年度 女性 吉耳

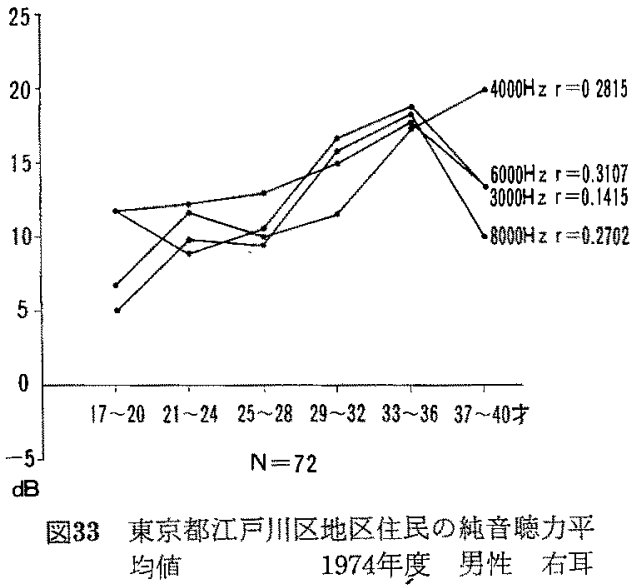

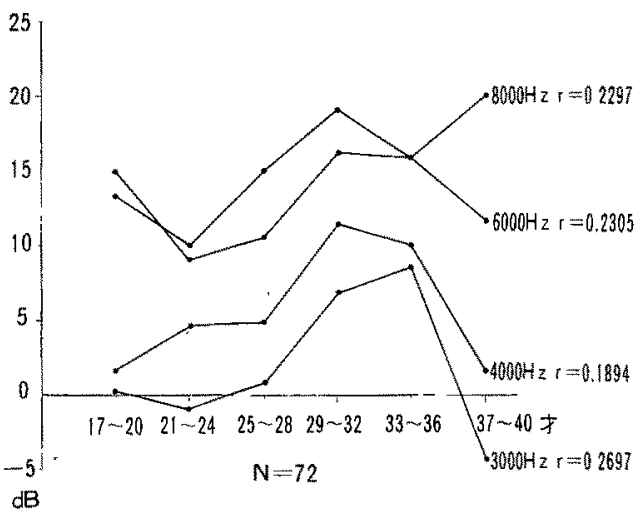

図34 東京都江戸川1区地区住純音㯖力平 均值 1974年度 男性 左耳

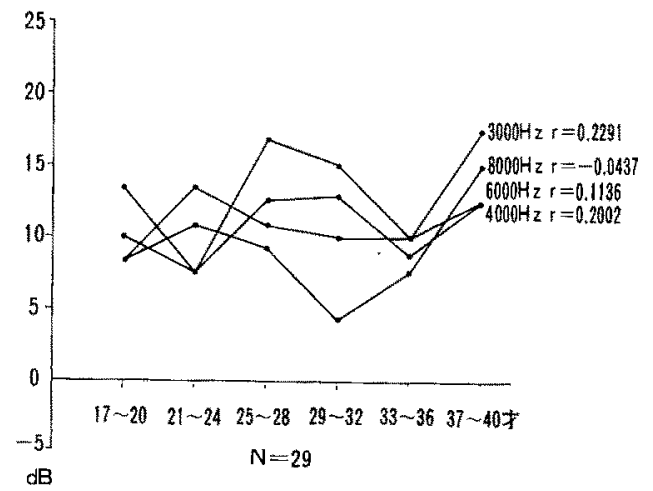

図35 東京都江戸川区地区住民の䌟意聴力平 均值 1974年度 女性: 右耳.

表 16 和歌山県那賀郡那賀町地区住民純音埴力の相関係数表

1976年度 女 性 $\mathrm{N}=55(17 \sim 36$ 歳 $)$

\begin{tabular}{|c|c|c|r|r|r|r|r|r|}
\hline 耳周波数 $\mathrm{Hz}$ & 250 & 500 & 1,000 & 2,000 & 3,000 & 4,000 & 6,000 & 8,000 \\
\hline 在 & 0.2644 & 0.2640 & 0.1726 & 0.0638 & 0.0943 & -0.0715 & 0.2112 & 0.1627 \\
\hline 左 & 0.1349 & 0.2139 & 0.2655 & 0.0865 & 0.0533 & 0.1577 & -0.1056 & 0.0438 \\
\hline
\end{tabular}

萑 17 東京都江戸川区地区住民能音聴力の相関係数表

1974年度 罗 性 $\mathrm{N}=72$

\begin{tabular}{|c|c|c|c|c|c|c|c|c|}
\hline 耳 側 & 250 & 500 & 1,000 & 2,000 & 3,000 & 4,000 & 6,000 & 8,000 \\
\hline 右 & 0.0972 & 0.0759 & 0.2340 & 0.2797 & 0.1415 & 0.2815 & 0.3107 & 0.2702 \\
\hline 左 & 0.3766 & 0.3877 & 0.3354 & 0.3053 & 0.2697 & 0.1894 & 0.2305 & 0.2297 \\
\hline
\end{tabular}




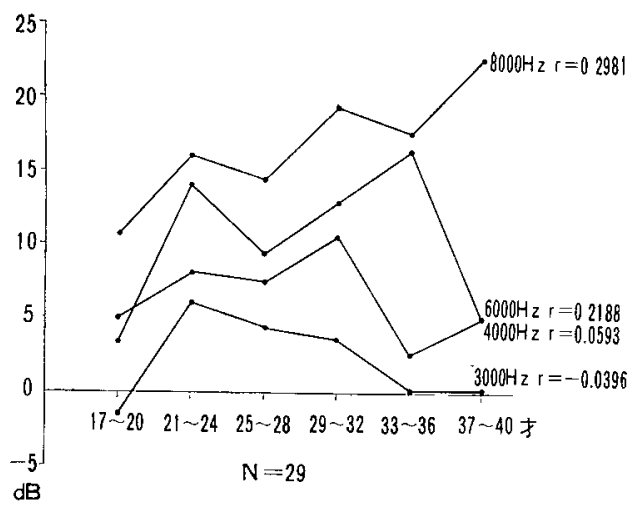

図36 東京都江戸川区地区住民の純音聴力平 均值 1974年度 女性 左耳

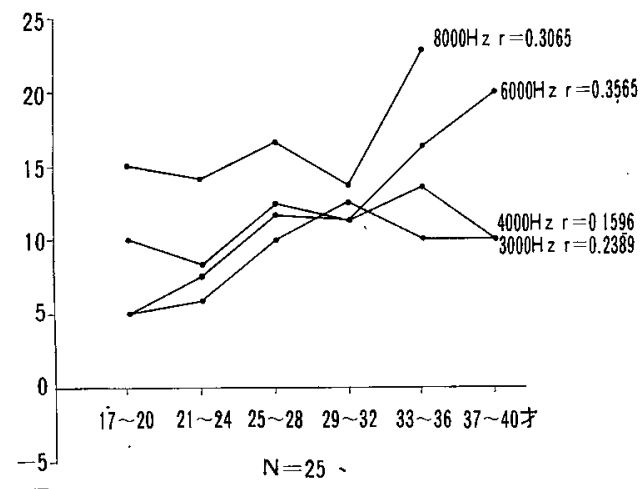

図37 東京都大田区羽田地区住民の純音聴力 平均值 1975年度 男性 右耳
(2) 東京都大田区羽田地区

i) 1975 年度, 被検者総数 73 名, うち有効数 72 名 144耳，男性25名50耳，女性47名94耳であった。

表19は，このグループのろち男性群両耳の年龄とき こえのレベルとの間の相関係数表である。図37は,各 4 年ごとに分けたグループの右耳゙のこえの平均值の年 齢的推移を示し，図38は，同群の左耳のあのである。

相関係数は比較的高 $<$, 右耳 $6,000 \mathrm{~Hz} \mathrm{r}=0.3565$, $8,000 \mathrm{~Hz} \mathrm{r}=0.3065$, 左耳 $2,000 \mathrm{~Hz} r=0.3732,6,000$ $\mathrm{Hz} r=0.2918,8,000 \mathrm{~Hz} \quad \mathrm{r}=0.3793$ を示して括り, 検查対象数が左右各 25 耳と少ないこと, TTS が無視 し得ない可能性もあるとしても，高音域でのきこえの レベルに対する影響は無視し得ないものがあるように

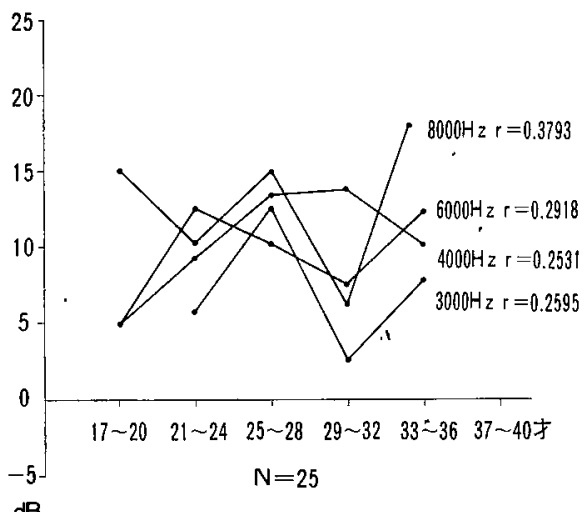

図38 東京都大田区羽田地区住民の純音聴力 平均傎 1975年度 男性 左耳

表 18 東京都江戸川区地区住民純音聴力の相関係数表

1974年度 女 性 $N=29$

\begin{tabular}{|c|c|c|c|c|c|c|c|c|}
\hline 耳周波数 $\mathrm{Hz}$ & 250 & 500 & 1,000 & 2,000 & 3,000 & 4,000 & 6,000 & 8,000 \\
\hline 右 & -0.0540 & -0.0062 & -0.0777 & 0.1395 & 0.2291 & 0.2002 & 0.1136 & -0.0437 \\
\hline 左 & -0.2112 & -0.1584 & 0.0617 & 0.0167 & -0.0396 & 0.0593 & 0.2188 & 0.2981 \\
\hline
\end{tabular}

表 19 東京都大田区羽田地区住民純音聴力の相関係数表

1975年度 男 性 $N=25$

\begin{tabular}{|c|c|c|c|c|c|c|c|c|}
\hline 洫 側 & 250 & 500 & 1,000 & 2,000 & 3,000 & 4,000 & 6,000 & 8,000 \\
\hline 右 & 0.1847 & 0.1222 & -0.1589 & 0.1357 & 0.2389 & 0.1596 & 0.3565 & 0.3065 \\
\hline 左 & -0.0619 & -0.0867 & -0.0641 & 0.3732 & 0.2595 & 0.2531 & 0.2918 & 0.3793 \\
\hline
\end{tabular}


患われる。

表20は，女性群の両耳の年齢ときこえのレベルとの 間の相関係数表である。

図39は，この群の右耳のきこえの平均値の年龄的推 移を示し, 図40は, 左耳の年齢的推移を示すあのであ る。

相関係数は右耳 $2,000 \mathrm{~Hz} \mathrm{r}=0.4155,3,000 \mathrm{~Hz} \mathrm{r}=$ $0.3321,4,000 \mathrm{~Hz} \quad \mathrm{r}=0.3269$, 左耳 $2,000 \mathrm{~Hz} \quad \mathrm{r}=$ $0,3958,3,000 \mathrm{~Hz} \mathrm{r}=0.3088,4,000 \mathrm{~Hz} \mathrm{r}=0.2926$, $6,000 \mathrm{~Hz} \mathrm{r}=0.2934$ 々年齢的な分布の偏り㹥あるが， 相当汇高檤を示している。

(3) 兵庫県伊丹市地区

i） 1973年度, 被検者総数 139 名, そのう方有効数 138 名 276 耳で, 受検者は全員女性である。

本調查で汻年龄的飞30歳以上の受検者が $80 \%$ 以上を 示めて敌り，各人のきこえのレベルと年柃との間の相 関をこのま变で求めるのに若干無理があるが，他地域 と同じ処理方式でコンピュー夕処理を行なった。

表21は，両耳のきこと年柃との相関係数表である。

図41は，右耳の 4 年ごとにわけたグループのきこ光 の平均値の推移であり，図42は，左耳のそれである。

相関係数蛙他の騷音地区のいずれよりも低く，特低 右耳の值は無騒音地域の人達と同等であったことが印 象的である。この理由についての検討は後記する。

左耳の相関係数は $2,000 \mathrm{~Hz} \quad \mathrm{r}=0.2030,3,000 \mathrm{~Hz}$ $r=0.1905$ 之若干高かったが，問題となるべき 4,000 $\mathrm{Hz}$ は $\mathrm{r}=0.1496,6,000 \mathrm{~Hz} \mathrm{r}=0.1131,8,000 \mathrm{~Hz}$ $r=0.0849$ といずれも低加っ。

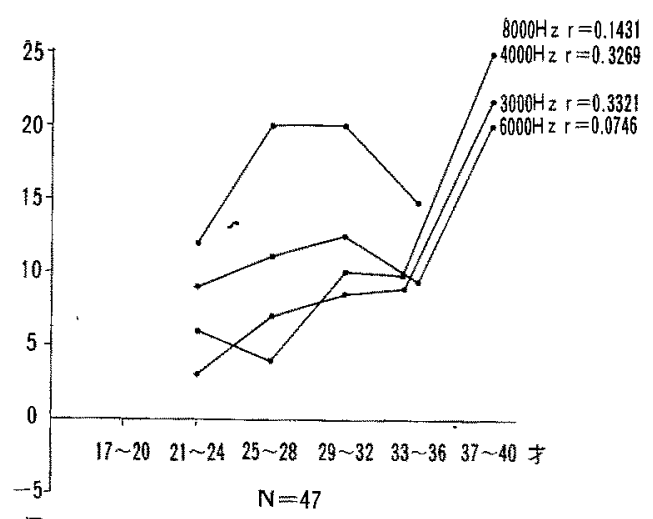

図39 東㞻都大田区羽田地区住民の純音聽力 平均值 1975年度 女性 右耳

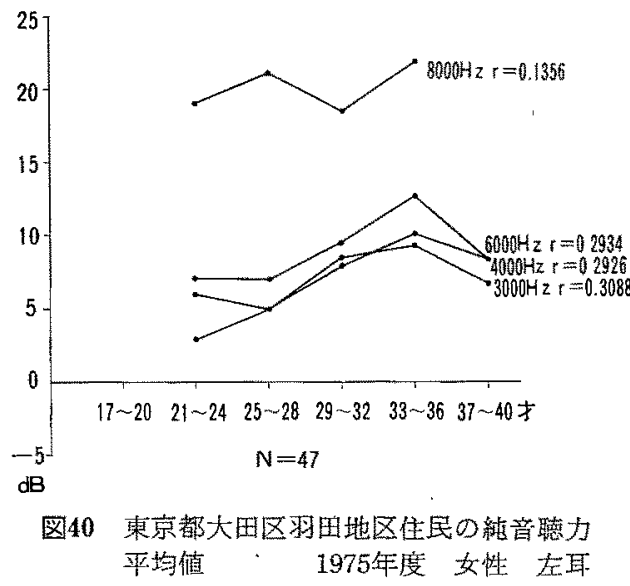

表 20 東京都大田区羽田地区住民純音德力の相関係数表 1975年度 女 性 $N=47$

\begin{tabular}{|c|c|c|c|c|c|c|c|c|}
\hline 耳 側 & 250 & 500 & 1,000 & 2,000 & 3,000 & 4,000 & 6,000 & 8,000 \\
\hline 右 & 0.0943 & 0.2165 & 0.1879 & 0.4155 & 0.3321 & 0.3269 & 0.0746 & 0.1431 \\
\hline 左 & 0.1759 & 0.2791 & 0.1492 & 0.3958 & 0.3088 & 0.2926 & 0.2934 & 0.1356 \\
\hline
\end{tabular}

表 21 兵庫罧伊丹市地区住民続音倰力の相関係数表

1973年度 女 性 $N=138$

\begin{tabular}{|c|c|c|c|c|c|c|c|c|}
\hline 耳周波数 $\mathrm{Hz}$ & 250 & 500 & 1,000 & 2,000 & 3,000 & 4,000 & 6,000 & 8,000 \\
\hline 耳在 & 0.1508 & 0.1159 & 0.1295 & 0.0817 & 0.0447 & 0.0612 & 0.0454 & 0.0432 \\
\hline 左 & 0.1625 & 0.1839 & 0.1878 & 0.2030 & 0.1905 & 0.1496 & 0.1131 & 0.0849 \\
\hline
\end{tabular}




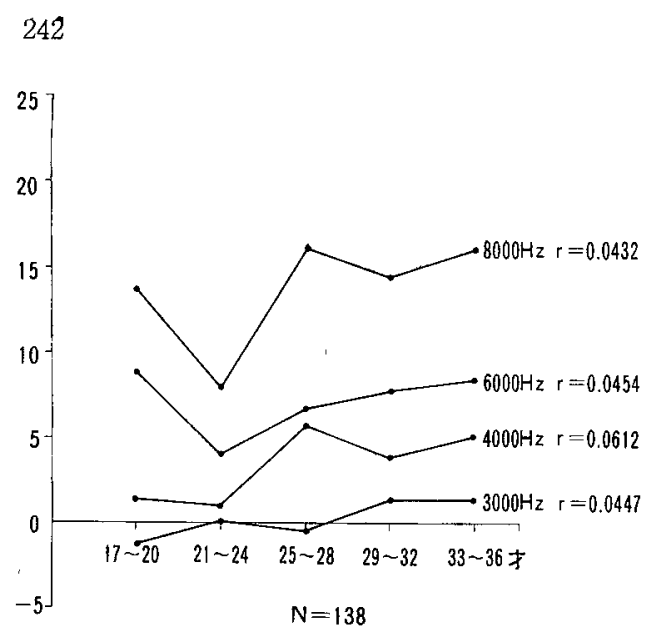

$d B$

図41 兵庫県伊丹市地区住民の純音聴力平均値 1973年度 女性 右耳

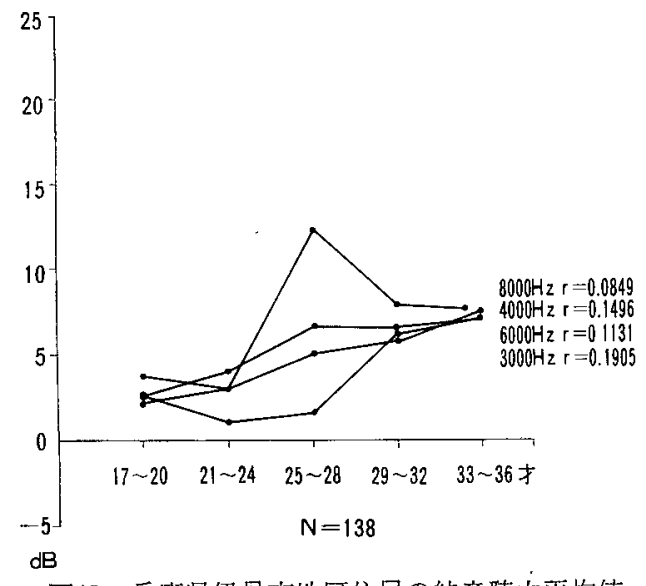

図42 兵宣県伊丹市地区住民の純音聴力平均值 1973年度 女性 左耳:

\section{ii) 1975 年度}

被検者 34 名, 有効数 33 名 66 耳, 対象者は全員女性で ある。調查連絡の手荤いから $3,000 \mathrm{~Hz}, 6,000 \mathrm{~Hz}$ の 調查は省かれているが,これ以外の調查方式はすべて， 前回調査と同様である。年㱓的飞も前回同様30歳以上 が72\%以上を占めていた。

表22は, この群の相関係数表である。

図43は，右耳の 4 年ごとに分けたグループの平均值 の推移であり，図44は，左耳のそれである。

この調查結果も，きこえと加齢の関係氏ついての常 識とは一致しない成績を示している。すなわち，20歲

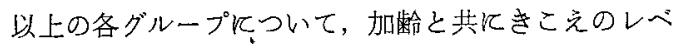
ルの平均が良くなっている周波数が右耳で $1,000 \mathrm{~Hz}$,

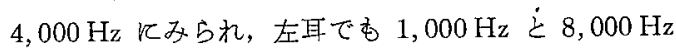

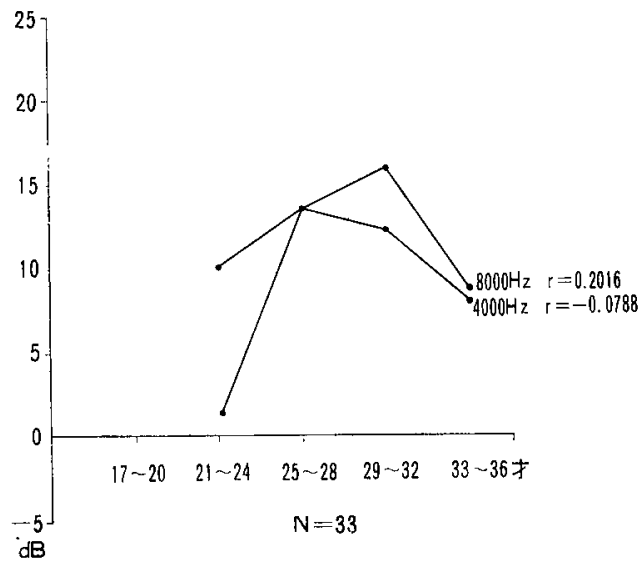

図43 兵庫県伊丹市地区住民の純音聴力平均值 1975年度 女性 右耳

表 22 兵庫県伊丹市地区住民純音聴力の相関係数表 1975年度 女 性 $N=33$

\begin{tabular}{|c|c|c|c|c|c|c|c|}
\hline 耳 側 & 125 & 250 & 500 & 1,000 & 2,000 & 4,000 & 8,000 \\
\hline 右 & 0.2058 & 0.0936 & 0.1103 & -0.2223 & -0.2506 & -0.0788 & 0.2016 \\
\hline 左 & 0.0676 & 0.1722 & 0.1509 & -0.0475 & 0.1506 & 0.1131 & -0.0446 \\
\hline
\end{tabular}

表 23 大阪府豊中市地区住民純音聴力の相関係数表

1976年度 女 性 $\mathrm{N}=80$

\begin{tabular}{|c|c|c|c|c|c|c|c|c|}
\hline 耳 側 & 250 & 500 & 1,000 & 2,000 & 3,000 & 4,000 & 6,000 & 8,000 \\
\hline 右 & 0.1248 & 0.1460 & 0.2094 & 0.0234 & -0.0632 & 0.0953 & 0.1890 & 0.2517 \\
\hline 左 & 0.1008 & 0.0544 & 0.0559 & 0.0712 & 0.0357 . & 0.0435 & 0.0600 & 0.1379 \\
\hline
\end{tabular}




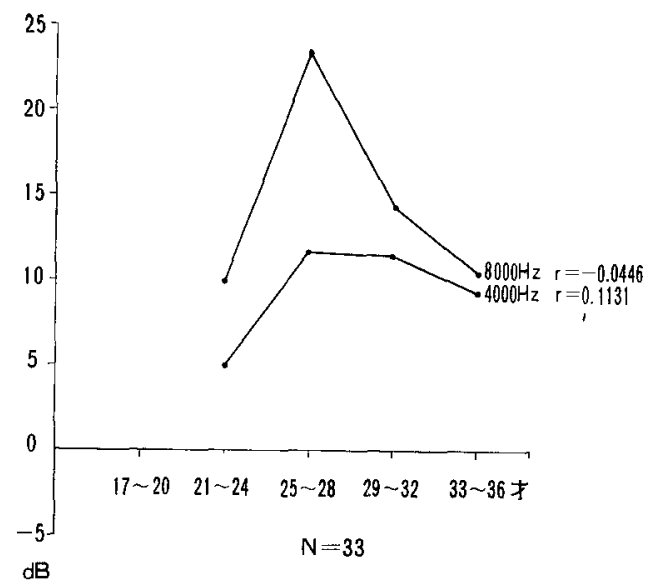

図44 兵軍県伊丹市地区住民の純音聴力平均值 1975年度 女性 左耳

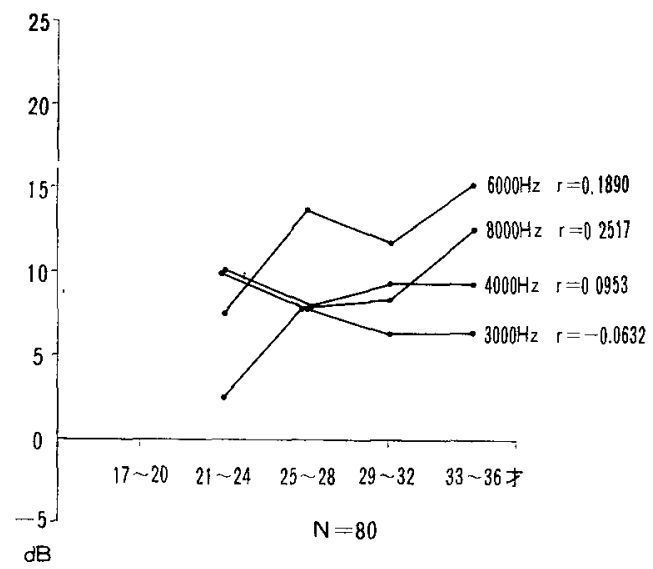

図45 大阪府豊中市地区住民の純音聴力平均值 1976年度 女性 右耳

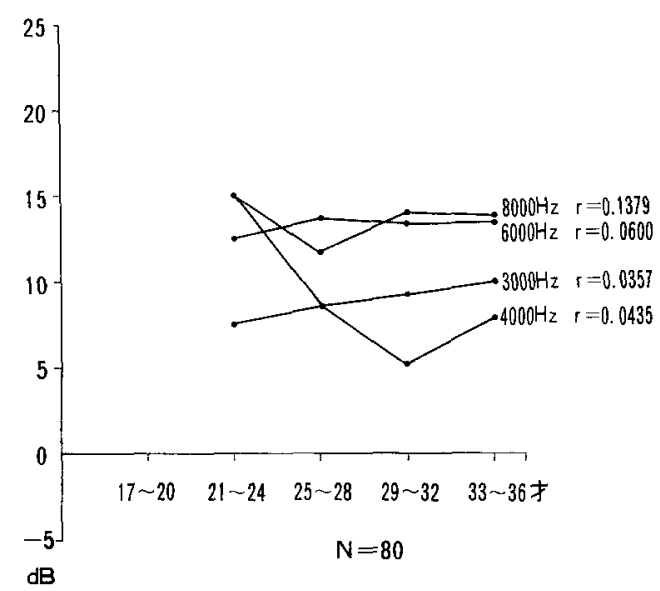

図46 大阪府豊中市地区住民の純音聴力平均值 1976年度 女性 左耳
に認められることである。高值を示したのは右耳8,000 $\mathrm{Hz} \quad \mathrm{r}=0.2016$ であったが左耳 $\mathrm{r}=0.0446$ とは差がな いとはいえない成績を示している。

(4) 大阪府豊中市地区

i） 1976 年度, 被検者総数 93 名, 万占有効数 80 名 160耳，対象者は全員女性である，

表23は，両耳のきこえと作齿との間の相関係数表で ある。

図45は，4年ごとにグループイ分けた右耳のきこえ の平均值の推移であり，図46は，左耳のそれである。

加齢に上る低下傾向は認められ学かった。

\section{考按とまとめ}

環境騒音については明確な定義はないが，ある地点 飞颃いて特定の音源のはっきりわかる蹑音のみでなく その生活環境に存在する不特定多数の騒音がまざって いるもの ${ }^{1)}$ と理解される。前述のごとく，その愳力に 挌よほす影響炕ついては記載が非常沙なく，また民 族間のそれぞれの周波数の域値差, 暗騒音の種類とレ ベルの差によって生ずる㭘查成績の違いを客観的に立

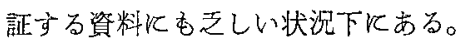

そこで著者らは㻴境騒音のレベルの低い山村, 漁村 などの無騒音地域に居住する人達と, 環境騒音の代表 として扱われている航空機騒音, 自動車騒音のレベル の高い地域居住する人達について，それらの騒音が この地域に居住する人達の純音聴力にどのような影響 を与えているかをみるために，ISO 規格オージオメ 一タと受話器を使い, 同じ検查方式で, 前記の受検条 件を満たす人達を対象飞検查を行ない，その成結につ いて，それぞれの周波数の相関係数，扔よび平均值の 年齿的推移より, 環境騒音の有無ならびそ純音の低下 傾向と騒音以外の聴力障害因子飞ついて検討を加える こととした。

Rosen $^{2)}$ らがアフリカに住むマバーン族とアメリカ のウィスコンシンの市民の聴力を比較するとマバーン 族の60 69歳はアメ引カ人の20～29藏の聴力に匹敵す ることを実証し，静かな環境住むマバーン族は大き な音をだす楽器を用いず，鉄砲も使用しないこと，そ れに血管の運動性がよく動脈硬化の少ないためである と解説している。一般に文明人の聴力が低下している のは食生活, ストレスなどが内耳の血液循環に悪影響 を拉よぼすためであると考えられている。

騒音が聴力比影響を括よぼすと騒音難聴となるが， その発症の説明には音王 $\times$ 時間説, 音圧 ${ }^{2} \times$ 時間説 $($ 等 
価エネルギー）説なジがあり，環境騒音の場合も同様 飞暴露時間，音圧が因子として重要であるよろに考兄 られる。

Lehmann ${ }^{3}$ 何騒音を 4 段階にわけた。

1） $30 \sim 65 \mathrm{~dB}$ (A) 怯心理反応を栝こす。

2） $65 \sim 90 \mathrm{~dB}(\mathrm{~A})$ 心理反応挌上び自律神経の反応 起起。

3) $90 \sim 120 \mathrm{~dB}(\mathrm{~A})$-2) 飞聴器障害が加わる。

4) $120 \mathrm{~dB}(\mathrm{~A})$ 以上 内耳障害が高度である。

の段階とわけ，騒音の障害度を説明している。Miller は $80 \mathrm{~dB}$ (A) の騷音沬頻回以，加規則的飞加わると 内耳障害を括こすと述へ，また加龄による難聴は騒音 と無関係炕進行するが，70 80 dB (A) より大きな騒

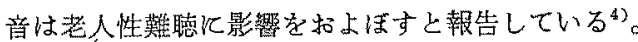

また Ward ${ }^{5}$ は男女の性差をみると，女性结男性よ りも低音 (1,000 Hz 以下) の騷音尤るTTSが起り 飞くく；逆炕高音 $(2,800 \mathrm{~Hz}$ 以上）では起りやすい という報告があり，これ法耳小筇の取縮が関係して いるといろ5)。しかし，こ礼らのいずれもが Lehmann ${ }^{32}$ の述べる第 2 段階以上のグループ㙖するすのであ り，30 65 dB (A) の1段階のグループKは心理的な 反応のみで聴力障害は起こらならとの考光が妥当のよ 万思和れる。今回の報告飞含まれる調查対象の居住 地域はいわゆる無騷音地域は Lehmann ${ }^{33}$ の符 1 段階 の環境下炕あり,有騷音地域はこの第 2 段階飞あって， Miller ${ }^{1}$ によよれば障害を起こしうる段階にあり，Lehmann $n^{3)}$ の分類では障害を起こす限界以下に含まれる ものである。

一方代招いてこのような純音㯖力の域值検查成績の 比較検討飞際して，聴力检查学行なら条件比ついても 慎重な配慮が必要であることは言うまでもないことで ある。

純臽聴力域值検查は，きこ光るか，きこ觉ないかの 境目の微小感賞の域値検查であるため, 極めて徽小な 音を確認しなければならない聴覚検査である。そのた め, 周囲の僅かな騷音条件の变化, 検査をうける人自身 のいろいろな身体条件汇よって，域值は相当汇变動す る。身体条件汇基ずく日中の変動幅でも Neuberger ${ }^{6)}$ 森”, 大和田 ${ }^{8}$, 立本 ${ }^{9}$, 山本 ${ }^{21)}$, 長尾 ${ }^{22}$ らの報告では変 動幅は $8 \sim 24 \mathrm{~dB}$ 程度と記されているし，椆田 ${ }^{18)(19) 20\rangle}$ の原因分析であある程度の誤差活兆れられないとして いる。まして，検查室の暗騒音のレベルが高い場合と か，うるさい場所加ら検查室飞天。て直ち飞検查する 場合など，本来の域值とは $20 \mathrm{~dB}$ 屯 $30 \mathrm{~dB}$ も異なった
值が本当の值のよう飞出てしまうことも京まするもの である。

そのような理由から，聴力検卒を行なう検查室はで きるだけ遮音，防音設備のゆき届いた静肃な部屋であ る必琶があり，暗騷音のレベルは， $50 \mathrm{~dB}(\mathrm{C})$ 以下， $30 \mathrm{~dB}$ (A) 以下でなけれね゙ならないとされている。

㭘査を受乾る人達の条件としては，大体同し㭙刻， たと六は午前10時から12時頃まで々か，午後なら 2 時 頃加ら5 時頃までが望变しく, 午前 8 時之か 9 時頃， 昼食の時間，あるいは夜間などの検査は不適当と考元 られる。

また，先記したようK，騷音のある場所がら検查 室㣔った場合飞は，TTS の状態机あるため，4,000 $\mathrm{Hz}$ 付近の周波数の域值吕大きく出やすく，误りを侵 主危険が少なくない。

以上のような理由から，少なくとも哄なって防音室 で行なった検查の成績を比較すること沬不可能で，環

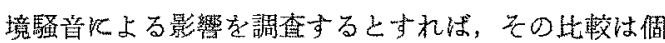
個の地域のグループKついて，暗騷音の影響をつけに くく，騒音汇よってPTS の起こりやすい4,6,8 kHz の低下倾向と扔の扔のの年路之の相関を追跡するほか 方法注当当らい。

臨床検査上, 必要な点は, この種の域値検查を行な ろ汇当って，被検者の NITTSを測ってはならないと いうことで，検查飞当っては检相前飞少なくとも30分 間は、静肃な部屋で安静をとる必要がある。このよう な配虑のないこの種の検查は誤差要因があまりにも多 く，検討の対衤たりえないと考兄る。

\section{無騷音地域について}

津軽石地区洛よび花輪 C地区のごとく，20歳より 35

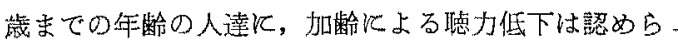
れない。特汇漁村である津軽石地区では177 名の女性 群炕この倾向が性っきりと現われている。男性群は30 名と小数であるが，花輪地区同様飞若干の障害傾向が ある。これは男性自身の傾向として考光るべきか，あ るいは同地域行 7 年以上居住しているという条件には 入るがそれ以前飞騒音地域あるいは騷音場の居住，ま

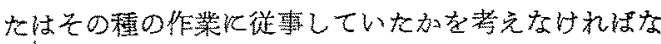
らない。

津軽石地区とほ滛隣接する純農村である花輪地区て あ，鳥や虫の声，時たまのバスの通過音しか音として 感じない無騒音地域であるにすかかわらず，1972年度 調查では，左右耳效称性飞 $4,000 \mathrm{~Hz}$ の低下傾向方 あり，女性群江も同様江右耳 $3,000 \mathrm{~Hz}, 4,000 \mathrm{~Hz}$ K 
低下傾向が垫められた。1974年度調㮩でも一部气の傾 向はあるようにす思かれるが，1975年度の調查で致相 関は全く認められなかった。これらの差は，する程 度, 同地域内での地域差も考光られる。

無騒音地域で注この年龄期間の女性群化きこえのレ ベルの但下傾向が無いということは棓い得るように考 える。

栃木県小川町片平地区の調查は，対像地域が極めて 閑静な純農村地域であるとあかかからざ，高い低下傾 向がみられたことは，花輸地区の一部功そうであった

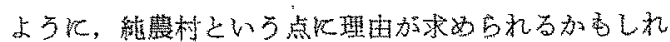

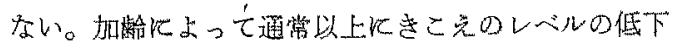

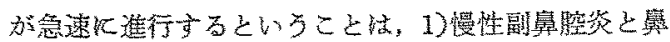
アレルギーの交替現象などの理由としてあげられてい る食生活の差, 2)聴器毒性を持つ可能性の方る残留震 薬の影蠁などを考えなければならないであろう。

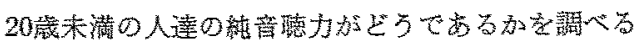
ために選んだ山形県寒河江地区の学校生徒では，年彩 層㤎他地区と異なるため，比較はできないが、、女性群 几低下傾向を否定できい結果得た。しかし男性群 では向上傾向が南り，男性群と女性群之の間江判然と はしないが；何らかの差を考学るべきかむしれない。

\section{騒音地域について}

騷音地域としては，兵庫県伊丹市地区，大阪附豊中 市地区，東京都羽田地区，東京都江輀川区地区を遙九 で検查を行なったが，最も低下傾向が大きく現われる と予想していた兵庫县伊丹市地区では，2回にわたる 調查です玨とんどこの傾向が否定された。

この理由として，(1)調楂対象者が条件には入ってい るが比較的騒音レベルの低い地域の人達であるのか，

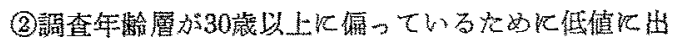
やすいのか，あるいは，(320歳前後の著い年齢層も含 めて，始め加らある程度聴力低下が起こり，その状熊

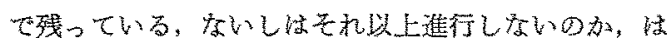
たまた(4)この地域の人達が騷音们対して特化抵抗力が 強いのかのいずれか，または可これらの組合壮が艺の 理由の上万炕思和れる。調查担当者の印象としては(2)

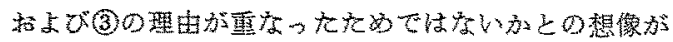
浮から゙。

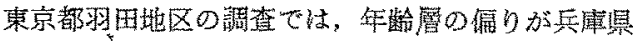
伊丹市地区と類似しているので，兵庯県伊丹市地区同 样の成續を期待したが，案沉相違して，男性群，女性 群とも熇音域で低下傾向がうかがわれた。

東京都江戸川区地区の調查性, 航空機騒音飞此乙量,

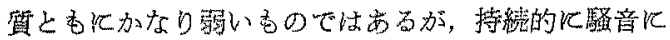
さらされているため等価エネルギー的な考方方からは ある程度の低下倾向が予想される。調查成績恃乞の予 想通りのすので，前記成樍のどとく，東京都羽归地区 飞次いで影響の考充られるものであった。例兑ば， 東京都羽田地区和上び江户川区地区の各男性群の右耳 $6,000 \mathrm{~Hz}$ の相関係数汒ついてい光壮，両者の相関係 数の閒の差がある加否かの检定では，Z変換汇より泪

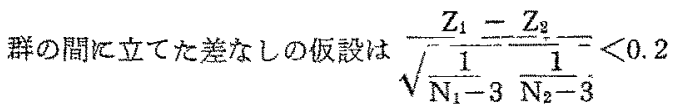
となり萧却できない。

今後さらK，同条件飞步ては省被検者(検盀対象) の数を加えて，占り客観性の高い成績を求める必要委

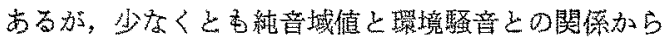
みると，騷音の樌類のいかん加加わらず，環境騒音 と呼ばれる騒音火さらされている人達には，その騒音

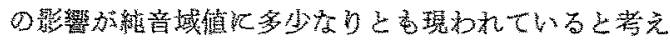
てよい上う汇思われる。これは各種の環境騒音汇常に 国亲れている都会生活者の持つ宿命之考兑てもよい。

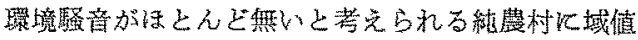
低下傾向が共通してみられたこと亿ついては，東北地 方，関東北部，近畿地方之いう地域差も考光なければ ならないので，他地域の資料も重亦て検討を加えてい きたい。

擱籍炕当り。本調查について多大の湖協力頂いた， 研究者所属機関の諸先生灾らび各地域の被検者各位 飞深筑すると共汇，

兵㢆県伊丹市役所, 矢埜与一市長他各位 大阪府豉中市役所, 下村輝雄市長件各位. 大阪国際空港ソディカルセンター，千葉隆造䧸士他 各位

東京都大田区役所公害対策部各位

宩京都游由区医師会, 潾田清二博士他各位 東京都大秝医師会，酒勾 睦博士他各位 東京都江戸川区役所，中里喜一区長他各位 巢京都江戸川区医師会, 梅沢董一博士他各位 岩手塄宫古市役所各位 岩手県立宮古病院職員各位。 山形県寒河江市大江町教育委員会各位 疗木県那須郡小川町，越井金四郎町長他各位 颜术県那須郡小川町医師会，関三郎博士他各位 和歌山県那賀郡那賀町役場職員各位ならび坂口貞 一郎氏に厚く御礼旰し上げます。 
本稿の主旨は, 第 17 , 18, 19 回日本才ージオロジー 学会, 第 77 回日本耳翼咽喉科学会 (東京, 1976), XI World Congress on Otorhinolaryngology (Buenos Aires, Argentine. 1977）火招いて発表した。

\section{The Influence of Environmental Noises on Normal Hearing Ability \\ Jun Okada et al. (Toho Univ.)}

The influence of the environmental noises which exist continually or periodically in the everyday life on the pure tone hearing ability were surveyed.

In noisy environments such as areas nearby an international airport and areas along the main traffic roads, and in noiseless environments such as agricultural and fishing villages, people living for a long period of time were the objects of this survey. The pure tone hearing test was done using the ISO standardized audiometer and earphone with the frequency from 250 to $8,000 \mathrm{~Hz}$.

As to each frequency, the presence of the influence of environmental noises, the dropping tendency of tone hearing ability, and other causes of the hearing impairment were studied and compared with the results of the correlation coefficient of age and hearing loss, and the change of average value with the age.

The results were as follows:

People living in the areas nearby the airport showed no tendency of pure tone hearing impairment. People living in the areas of loud traffic noises and in agricultural villages showed slight hearing impairment. However, in fishing villages no hearing impairment was observed.

\section{参考文 献}

1）守田 栄, 他: 騒音用語事典, オ一ム社, 1976 .

2) Rosen, S., et al.: Presbycusis study of a relatively noise-free population in the Sudan. Ann. Otol., 71; 727-743, 1962.

3) Lehmann cited by Wende, E., und Kötter, J.: Mensch und Umweltärm. Internist, 14; 244-229; 1973.

4) Miller, J. D.: Effects of noise on people. J.A.S.A., 56; 729-764, 1974.
5) Ward, W. D.: Temporary threshold shift in males and females. J.A.S.A., 40; 478-485, 1966.

6) Neuberger, et al.: Hörschwelle und Sympathicotonus, ihre cyclische Konkordanz und temporäre Koinzidenz im 24 Stdrhythmus. Archiv Ohren-usw, Heilk-u.z. Hals-usw. Heilk., 179; 237, 1962.

7）森 三樹，他：聴力変化判定の 基準汇関する研 究. 日耳耳䙹, $\cdot 70 ; 11,1828,1967$.

8). 大和田健二郎, 他: 最小可聴音の変動について. 耳喉，26；1，11，1954.

9）立木 孝，他：オージオグラムの長期間変動. Audiology Japan, 7; 35, 1964.

10) Glorg, A. and Davis, H.: Age, noise and hearing loss. Ann. Otol., 70; 556-571, 1961.

11) Shepherd, M.: Pollution, noise, and mental health. Lancet, Feb. 8; 322, 1975.

12) Hammelbuy, E.: Noise, man and law. ORL., 35; 363-370, 1973.

13）長田泰公: 騷音の健康被害. 公衆衛生院研究報告. 22 ; (4), 209-227, 1973.

14）設楽哲也：日本人高齢者の聴力炏関する研究. 日 耳鼻，63；(7)，1551-1566，1960.

15）横内幸子：聴力の生理的年齢変化飞ついて，日耳 餅, 67; (9), 1307-1319, 1964.

16）切替一郎，他：聴力の年龄変化, Audiology Japan, 12; (2), 173-177, 1969.

17）岡田 諒：騒音難㯖飞ついて。東邦医会誌， 21; (4・5), 307-315, 1974.

18）岡田 棓：純音聴力域値検查で生ずる誤差の原因 分析. Audiology Japan. 19;(6), 310-318, 1976.

19）岡田諪：臨床医科炡とっての純音聴力域値検査 の問題点飞対する検討. 耳展, 19; (5), 521-530. 1976.

20) 岡田 諒: 純音聴力域值検查の問題点. 日耳耳鼻. $80 ;(3), 305-308,1977$.

21）山本昌彦，他：純音域值聴力検查飞招ける域值飞 対する追求（その1）, 耳展，19;（3），295-298, 1976.

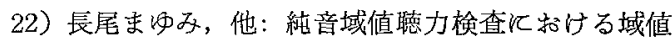
飞ついての研究（その 2)，耳展. 20；(1)，29-

35, 1977.

23) Kell, R.L, et al: Hearing thresholds of an Island population in North Scotland. International Aodiology 9; 334-349, 1970.

（受付 52.3.15) 